by Ron Clowes ${ }^{1}$, Frederick Cook ${ }^{2}$, Zoltan Hajnal ${ }^{3}$, Jeremy Hall ${ }^{4}$, John Lewry ${ }^{5}$, Stephen Lucas ${ }^{6}$, and Richard Wardle 7

\title{
Canada's LITHOPROBE Project (Collaborative, multidisciplinary geoscience research leads to new understanding of continental evolution)
}

\author{
1 LITHOPROBE Secretariat, 6339 Stores Road, University of British Columbia, Vancouver, BC, V6T 1Z4, Canada. \\ (E-mail: clowes@lithoprobe.ubc.ca) \\ 2 Department of Geology and Geophysics, University of Calgary, Calgary, AB, T2N 1N4, Canada. \\ 3 Department of Geological Sciences, University of Saskatchewan, Saskatoon, SK, S7N 5E2, Canada. \\ 4 Department of Earth Sciences, Memorial University of Newfoundland, St. John's, NF, A1B 3X5, Canada. \\ 5 Department of Geology, University of Regina, Regina, SK, S4S 0A2, Canada. \\ 6 Continental Geoscience Division, Geological Survey of Canada, Ottawa, ON, K1A 0E8, Canada. \\ 7 Geological Survey Branch, Department of Mines \& Energy, St. John's, NF, A1B 4J6, Canada.
}

LITHOPROBE is a scientific project of international stature and the largest earth science research project ever undertaken in Canada. It comprises a series of research teams carrying out collaborative, multidisciplinary investigations of the nature and evolution of the Earth's lithosphere in ten carefully selected transects (study areas) on the Canadian landmass and surrounding continental margins. The project began in 1984 and will conclude in 2003 following syntheses of transect studies and a pan-LITHOPROBE synthesis. In this review, three examples - (1) the Late Archean-Paleoproterozoic assembly of northeastern Laurentia, (2) evolution of the Paleoproterozoic Trans-Hudson Orogen, and (3) development of the Mesozoic-Tertiary southern Canadian Cordillera - exemplify the extensive results. (1) In remote Labrador and northern Quebec, tectonic development of northeastern Laurentia occurred from about 2.5 to $1.7 \mathrm{Ga}$. It involved the convergent northward drift of two Archean cratons, Superior to the west and Nain to the east, and their ultimate collision with the more northerly Rae Province of the Canadian Precambrian Shield. These movements led to the generation of two orogens, initially the more eastern Torngat Orogen and later the New Quebec Orogen. Primary tectonic activity was brought to a close by post-collisional northerly indentation of the Superior craton and reactivation of the Torngat Orogen. (2) In Saskatchewan and Manitoba, the Paleoproterozoic Trans-Hudson Orogen is the best exposed and most complete orogenic belt of a network of such belts formed by collision of older Archean microcontinents. Understanding of its architecture and tectonic history has been changed fundamentally by LITHOPROBE research. This has resulted in a new working model, chronologically well constrained, for tectonic evolution of the orogen between 2.4 and 1.7
Ga. A previously unknown Archean microcontinent has been identified, and the economically important greenstone belt of the Saskatchewan-Manitoba borderland has been revealed to be a collage of oceanic/arc volcanic assemblages that were later intruded and overlain by volcanic, plutonic, and sedimentary rocks. (3) In British Columbia, the much younger (Phanerozoic) orogen of the southern Canadian Cordillera was the first in which the so-called "exotic" terranes were recognized as fundamental building blocks of the continent. Among many contributions, LITHOPROBE studies in the southern Cordillera have shown that terranes observed on the surface are decoupled from their mantle and lower crust and attached as thin flakes to the craton, and that a thin lithosphere underlies the central part of the orogen. LITHOPROBE has brought many benefits to Canada. Other countries may well find that similar, collaborative, multidisciplinary research projects in the earth sciences are comparably beneficial to them.

\section{What is LITHOPROBE?}

LITHOPROBE is Canada's national, collaborative, multidisciplinary, earth science research project established to develop a comprehensive understanding of the evolution of the northern half of North America. Canada's landmass is a complex geological mosaic representing four billion years of continental growth, destruction and reorganization. How the current configuration was established and the nature of the geological processes involved are fundamental questions in earth science that have implications which transcend the bounds of North America. Knowledge of the composition and geometry of this continental amalgam in three spatial dimensions, and of its evolution during the fourth (temporal) dimension, also is important in exploring for buried mineral and hydrocarbon resources, and for understanding earthquake and volcanic hazards. LITHOPROBE is exploiting the opportunity afforded by the variable geology of Canada to address these questions. 


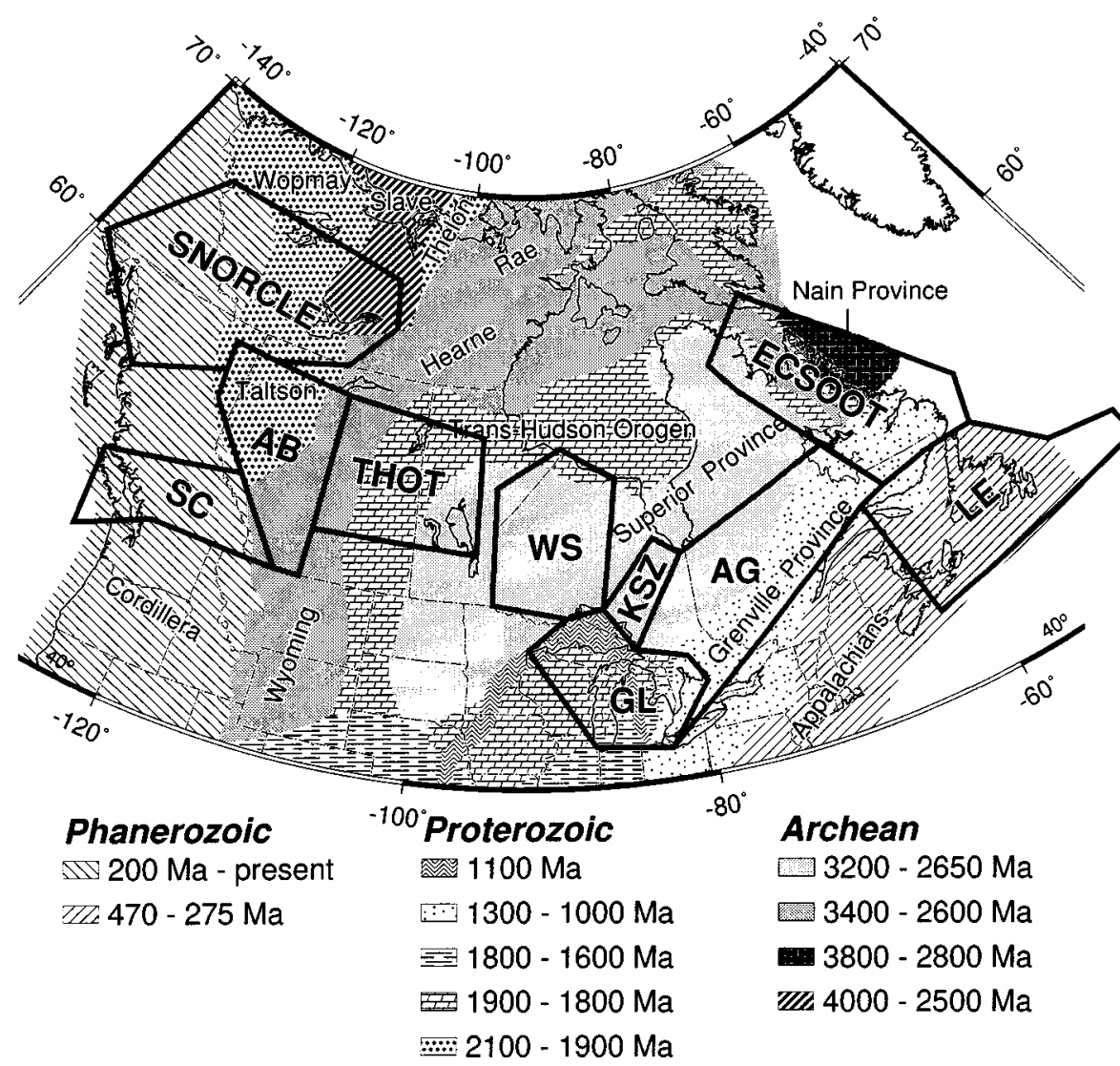

Figure 1 Location of LITHOPROBE transects (study areas) on a simplified tectonic element map of northern North America. The transects are: SC-Southern Cordillera; AB - Alberta Basement; SNORCLE - Slave-Northern Cordillera Lithospheric Evolution; THOT - Trans-Hudson Orogen; WS - Western Superior; KSZ - Kapuskasing Structural Zone; GL - Great Lakes International Multidisciplinary Program on Crustal Evolution (GLIMPCE); AG - Abitibi-Grenville; LE - Lithoprobe East; and ECSOOT - Eastern Canadian Shield Onshore-Offshore.

A coordinated yet highly decentralized research program, LITHOPROBE's principal scientific and operational components are built around a series of ten transects or study areas (Figure 1). Each of these is focussed on carefully selected geological features of the North American continent which represent globally significant geotectonic processes. The transects span the country from Vancouver Island to Newfoundland and from the United States border to the Yukon and Northwest Territories; and geological time from 4 Ga to the present. For each transect, an integrated scientific program addresses fundamental problems of the structure and evolution of the lithosphere and is carried out by a multidisciplinary transect team headed by a Transect Leader(s). Within each transect, the scientific program is spearheaded by seismic reflection investigations. However, inclusion of all other applicable geological, geochemical and geophysical subdisciplines within the solid earth sciences provides the scientific context that binds the program into a cohesive, comprehensive investigation. This emphasis on multidisciplinary science distinguishes LITHOPROBE from other national programs which focus more specifically on seismic reflection profiling [e.g., Consortium for Continental Reflection Profiling (COCORP, U.S.A.); British Institutions for Reflection Profiling Syndicate (BIRPS, United Kingdom); Deutsches Kontinentales Reflexionsseismiches Program (DEKORP, Germany); and Étude de la Crôute Terrestre en France par Méthode Sismique (ECORS, France)]. Together, the ten LITHOPROBE transects represent a focused effort toward an enhanced understanding of how the North American continent has evolved to form the present Canadian landmass. A primary effort during the remaining years of the project will be to synthesize results through a series of pan-LITHOPROBE studies that address globally significant problems in earth sciences.

This paper provides information on LITHOPROBE, regarded by many as the most successful national geoscience project ever undertaken, to the international earth science community. Part of LITHOPROBE's success derives from its history and structure, so a summary of these is provided. Scientific results are the raison d'être for any scientific project, but with about 1000 publications now representing the scientific output from LITHOPROBE, only a very limited part of this output can be illustrated herein. Hence, this paper highlights three recent summaries which underscore the project's multidisciplinary approach. An earlier review paper (Clowes et al., 1992) summarized scientific results to the early 1990s. Finally, plans for the pan-LITHOPROBE synthesis and benefits the project has brought to Canada are presented. For those scientists who would like to know more about LITHOPROBE, or access our publication list (by transect), this information is now available at the project's web site (http://www.geop.ubc/Lithoprobe).

\section{A brief history}

LITHOPROBE was initiated through the efforts of 'grassroots' solid earth scientists from the universities and the Geological Survey of Canada (GSC) who recognized the need for a dedicated project of high scientific significance to provide a flagship for, enhance the quality of, and bring cohesion to, their discipline. The concept of LITHOPROBE as a project evolved from a 1981 meeting of university geoscientists to discuss "Earth Sciences in the Eighties", sponsored by the Natural Sciences and Engineering Research Council of Canada (NSERC), and similar ideas being discussed at the GSC (CANDEL, 1981). Subsequently, a LITHOPROBE Steering Committee, comprising highly respected representatives from academia, the GSC and the petroleum and mining industries, was formed. Further broadbased discussions followed. In 1983, the GSC committed funds for a preliminary geophysical program to be run in 1984, and LITHOPROBE academics applied to NSERC for funds for the geophysical program and one of "supporting geoscience studies". The project was funded in 1984-85 for a 1-year Phase I preliminary program with primary scientific activity on Vancouver Island, part of the Southern Cordillera Transect, and some preliminary activity in the Kapuskasing Structural Zone Transect (Clowes, 1984; Clowes et al., 1984). During the same year, a marine seismic reflection survey, to become part of the Lithoprobe East Transect, was conducted off the northeast coast of Newfoundland as part of the GSC's Frontier Geoscience Program. These and all subsequent activities are illustrated by transect and year in Figure 2 .

During Phase I activities and extending throughout 1984 to 1986, development of a Phase II proposal, that received strong support through a 1985 national LITHOPROBE workshop, continued. Simultaneously, analysis of results from Phase I proceeded and support from the operations budget of the GSC enabled acquisition of multichannel seismic reflection data in the southeastern Cordillera in 1985 and provided the Canadian contribution to the 1986 Great Lakes International Multidisciplinary Program on Crustal Evolution (GLIMPCE) Transect, thereby maintaining important momentum. The GSC Frontier Geoscience initiative also continued its activities 


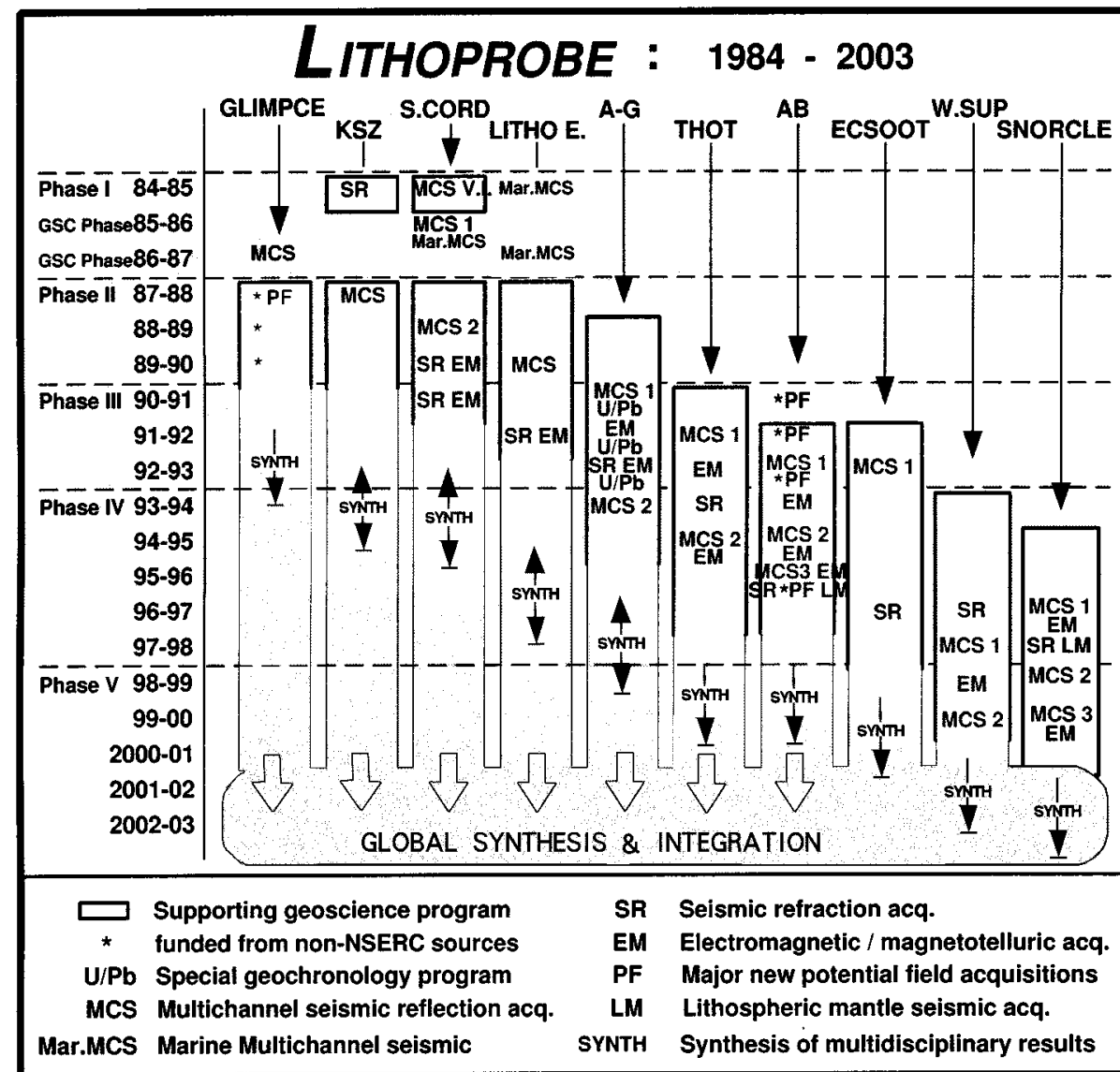

Figure 2 Summary of LITHOPROBE scientific activities and work plan, 1984-2003.

Phases II and III are shown as 3-year periods and Phases IV and V as 5-year periods, consistent with the funding profile and peer review processes established by NSERC. Phase $V$ will bring the project to its planned conclusion. Transects and their locations are shown in Figure 1.

on the continental margins, which contributed further to the Southern Cordillera and Lithoprobe East transects.

Outstanding results from Phase I and indications of more quality results from the interim reflection surveys, coupled with a very strong Phase II proposal to NSERC and the GSC, led to full establishment of the project in 1987 with a 5-year scientific program, subject to review and reapplication during the third year. In addition to the four transects already mentioned, funds were provided to initiate research in the Abitibi-Grenville Transect. At this stage, the Steering Committee had completed its responsibilities and the present organizational structure of the project was established (see below).

As part of the development of the project for the next phase, a call for, and rigorous national/international evaluation of, new transect proposals from the scientific community was undertaken. Following this procedure, three new transects (Trans-Hudson Orogen, Alberta Basement, and Eastern Canadian Shield Onshore-Offshore or ECSOOT) were incorporated into the scientific program for the Phase III Proposal, which was strongly supported by NSERC and the GSC with funding for 1990-1991 to 1992-1993. A similar procedure was followed for the Phase IV Proposal, which added two new transects (Western Superior and Slave-Northern Cordillera). NSERC and the GSC confirmed a 5-year award for the period 1993-1994 to 1997-1998.

In addition to the continuous, core funding provided by the two national organizations, strong support has been received from provincial/territorial geological surveys, which directed internal research activities to LITHOPROBE objectives when work was within their jurisdictions, and the mineral and petroleum industries, which contributed cash, data and logistical support within study areas of their interest. During 1997, the LITHOPROBE Phase V Proposal, subtitled "The Evolution of a Continent Revealed", was pre- pared and submitted to NSERC with a request for funding from 1998-1999 to 2002-2003 to bring the project to conclusion. Following another round of rigorous, international/ national peer review, NSERC awarded full funding that will allow LITHOPROBE to complete its planned scientific program.

\section{How does LITHOPROBE work?}

LITHOPROBE is a decentralized network of multidisciplinary scientific studies and collaborating scientists from across the country, but one that still requires centralized coordination. Thus a specialized organizational structure was developed early in the project's history to ensure the constancy of LITHOPROBE's role as a national scientific program (Figure 3). A Board of Directors is ultimately responsible for all programs, policies and expenditures; and is accountable to the primary funding agencies, NSERC and the GSC, for the efficient, effective, and economical operation of LITHOPROBE. The remainder of the organizational structure consists of operational and advisory components.

The advisory component includes a Scientific Committee and six subcommittees. The Scientific Committee is the senior scientific advisory body, comprising eleven highly regarded scientists, whose responsibility is to ensure the most effective scientific and technical direction for the project. Three disciplinebased subcommittees (Geology \& Geochemistry, Electromagnetic \& Other Geophysics, and Seismic \& LITHOPROBE Seismic Processing Facility) provide recommendations and advice on a range of scientific matters related to the applicable disciplines and on the application of those disciplines in all transects. The University Sup-

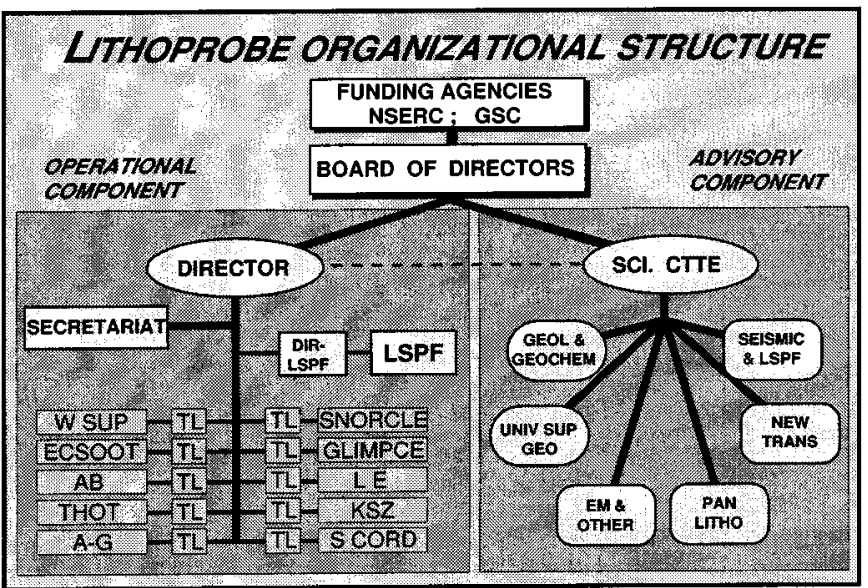

Figure 3 LITHOPROBE organizational structure. TL - Transect Leader; LSPF - LITHOPROBE Seismic Processing Facility. Subcommittees of the Scientific Committee are Geology and Geochemistry, Electromagnetics (EM) and Other Geophysics, Seismic and LSPF, University Supporting Geoscience Projects, Pan-LITHOPROBE and New Transects (no longer extant). The Secretariat includes the Director, Administrative Assistant, Operations Manager, Secretary, and part-time Communications Adviser. 
porting Geoscience Projects (USGP) Subcommittee is established each year to provide an objective and thorough peer evaluation of applications received for the annual internal grants competition through which many university-based scientists receive support for scientific investigations of relevance to the project. Procedures for these evaluations follow as closely as possible those established by NSERC for its grant selection committees, including the use of external referees. The grants competition is fundamental to ensuring participation of the best and most appropriate scientists, while guaranteeing equal opportunities for all interested scientists to become involved.

Long-range planning has been an essential component of LITHOPROBE. During previous phases of the project, when new transects were being planned, the Scientific Committee made a national call for new transect proposals that were competitively evaluated by an ad hoc New Transects Evaluation Subcommittee. As LITHOPROBE is brought to completion during the next five years, the Pan-LITHOPROBE Subcommittee, which was established in 1996, will provide advice, direction and comments on syntheses of results from all transects which relate to new understanding of the overall structure and evolution of northern North America, and the processes involved in that evolution.

The operational component of LITHOPROBE comprises the Director, Secretariat, LITHOPROBE Seismic Processing Facility, and the network of ten transects (Figure 3). The Director is the head of the project, providing overall scientific leadership, direction, coordination, and communication. The Secretariat, headed by the Director, is the central network node which provides communication and coordination for all components of the project. Among other duties, the Secretariat arranges Board and committee meetings, prepares and administers the budget, develops public outreach material, maintains the publication list and WWW site, oversees major contracts for field work, and runs the USGP grants competition. A parttime communications adviser assists with LITHOPROBE's extensive public outreach program. This involves two primary approaches: (1) to the print and electronic media for spreading information about the project; and (2) to diverse groups such as teachers, industrial representatives and political leaders for educational purposes (and to assist with fund-raising). In the interests of making LITHOPROBE as widely known as possible, a brochure (in English and French), a slide set with captions and narrative text (again in both languages), the internet, a display booth, etc. are used. CD ROMs and video material are planned.

LITHOPROBE's multidisciplinary scientific program is spearheaded by seismic reflection investigations because reflection images provide the most directly applicable information at depth. The LITHOPROBE Seismic Processing Facility (LSPF) is an efficient research partnership between the central site, located at the University of Calgary, and its associated national network of seismic research nodes, located at nine universities and three offices of the GSC. The LSPF was set up to fully exploit the extensive, and expensive, database of seismic reflection data to be acquired during the lifetime of the project. The LSPF also convenes regular thematic workshops on seismic studies which involve most of the seismologists (including graduate students and PDFs) active in LITHOPROBE.

The network of Transect Teams, each headed by a Transect Leader(s) and comprising scientists from all sectors who are actively participating in the scientific programs, are the key to achieving the scientific objectives of the transects. To facilitate the multidisciplinary interaction, each transect holds an annual workshop during its active period at which the most recent science is presented and discussions take place. Each workshop produces a volume of the contributions that become part of LITHOPROBE's numbered publications and are distributed widely by the Transect Leaders and the Secretariat. The extensive scientific participation in the project, now numbering more than 750 individuals since the project started, devolves from the decentralized transect approach.

\section{Three illustrative examples of results from LITHOPROBE studies}

For a project as extensive and long-running as LITHOPROBE, any review can only provide a flavor of the scientific results. Here, we illustrate the scientific program with key results from three of the ten transects. They represent different regions of Canada, from the east (ECSOOT in northern Labrador and Quebec) to the middle (TransHudson Orogen in Saskatchewan and Manitoba) to the west (southern Cordillera in British Columbia), different ages (Archean to Mesozoic), and different stages of transect development.

\section{Unraveling the Precambrian evolution of Northern Labrador}

The Archean cratons of Laurentia and Baltica are surrounded by Proterozoic mobile belts formed from 1.95 to $1.0 \mathrm{Ga}$ and analogous in scale and form with modern orogens. Paleoproterozoic belts on the northern side of the cratons involve large-scale reworking of Archean crust, attributable to indentation tectonics (Hoffman, 1990), and crustal-scale overthrusting analogous to the India-Asia collision. In contrast, the Paleoproterozoic belts south of the cratons are dominated by juvenile, accreted, arc-derived crust, which is indicative of a long-lived open margin along the southern edge of LaurentiaBaltica, analogous to Cordilleran-style tectonics involving a longlived passive margin and later accretion of terranes.

LITHOPROBE's Eastern Canadian Shield Onshore-Offshore Transect (ECSOOT; Figure 1) is focused on studies of the processes by which the northeastern Canadian (Laurentian) Shield evolved. The study area, in Labrador and eastern Quebec (Figure 4), includes (1) two large Archean cratons (the Nain Province, formerly part of the North Atlantic craton that extends through Greenland to NW Europe, and the Superior Province); (2) a smaller block of Archean crust (now in the core zone of the Southeastern Churchill Province) trapped between the two larger cratons as they moved together; and (3) five Proterozoic orogens, two of which (the New Quebec and Torngat orogens) suture the three Archean blocks, whereas the others record the progressive southerly accretion of juvenile crustal material to the growing Laurentian continent. The summary presented here provides results involving the Archean blocks and their stitching orogens.

\section{Geotectonic background}

The Nain Province, part of the North Atlantic craton, is divided into two major blocks, Saglek [comprising Early Archean (3.8-3.3 Ga) granulite-facies gneisses] and Hopedale [mid- to late-Archean (ca. $3.1-2.8 \mathrm{Ga}$ ), high- to intermediate-grade rocks], separated by a postulated suture (Figure 4). Amalgamation occurred ca. 2.5 Ga (Connelly and Ryan, 1996), with uplift to current exposure levels prior to 2.0 Ga. The Superior Province in the transect area consists of highgrade gneisses of ca. 2.7-2.6 Ga age, unconformably overlain by sedimentary rocks of the New Quebec orogen. A third Archean block lies within the core zone of the southeastern Churchill Province where it has been entirely reworked by Paleoproterozoic deformation.

The southeastern Churchill Province (Wardle and Van Kranendonk, 1996) resulted from oblique convergence of the Superior and Nain cratons, trapping intervening belts of Archean gneiss (the core zone) and juvenile crust, which are sutured against the cratonic jaws of this orogenic vice by the New Quebec and Torngat orogens (Figure 4; Hoffman, 1988). The New Quebec Orogen (Wares and Goutier, 1990) consists of low-grade continental margin rocks disposed in a west-facing fold and thrust belt which is underlain by basement of the Superior Province. The eastward extent of Superior crust has not been firmly established but may be approximated by the Lac Tudor shear zone (LTSZ, Figure 4). 


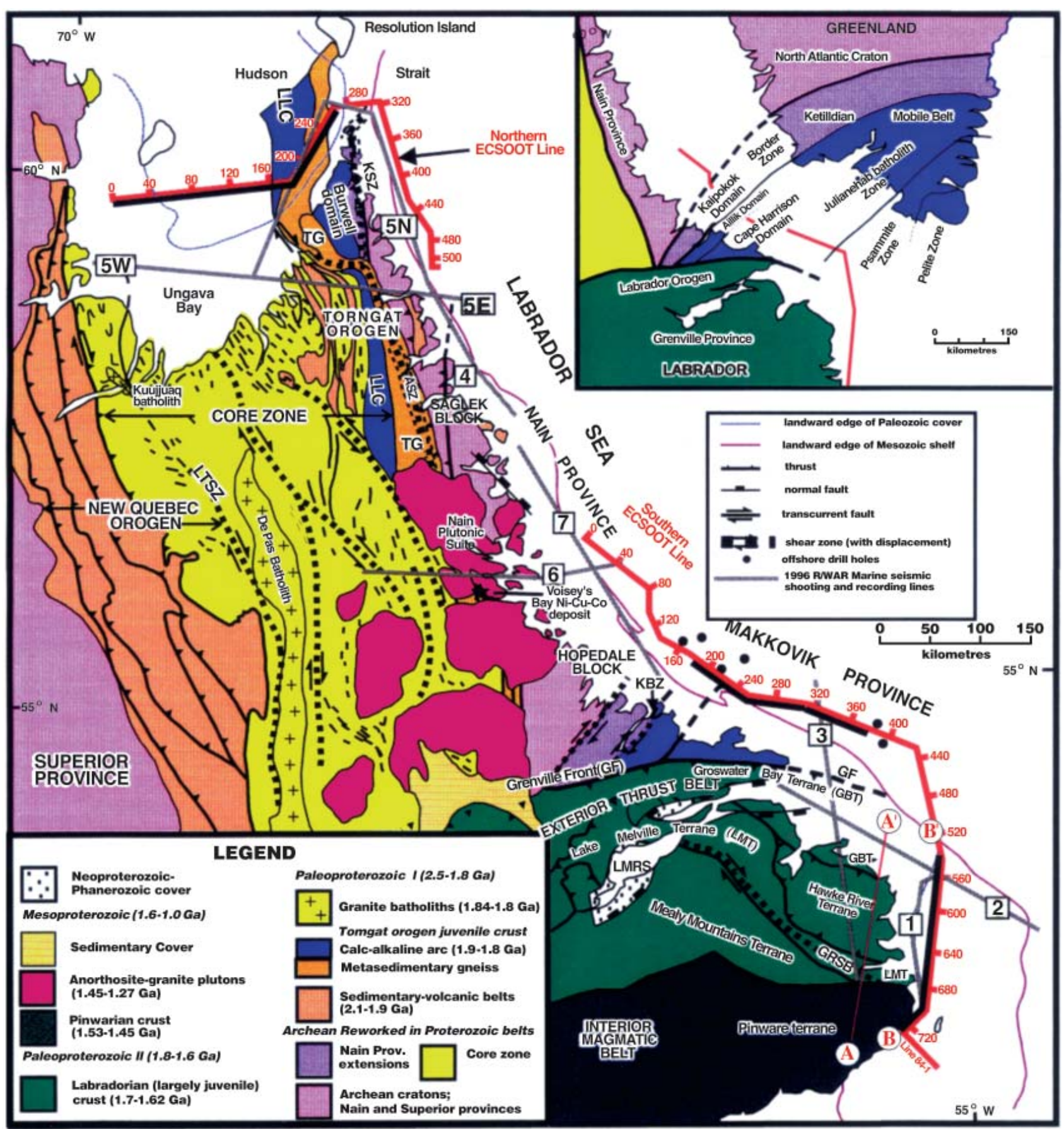

Figure 4 Tectonic map of ECSOOT region in Labrador and NE Quebec. Red lines show location of marine seismic reflection profiles; ticks indicate distances in kilometers along the lines. Grey lines are 1996 seismic refraction/wide-angle reflection profiles (offshore shooting, offshore and onshore recording). ASZ - Abloviak shear zone; GBT - Groswater Bay terrane; GF - Grenville front; GRSB Gilbert River shear belt; KBZ - Kaipokok Bay zone; KSZ - Komaktorvik shear zone; LLC - Lac Lomier complex; LMRS - Lake Melville rift system; LTSZ - Lac Tudor shear zone; TG - Tasiuyak gneiss terrane.

The interior of the southeastern Churchill Province is now regarded as a composite zone that comprises Superior crust in the west (James et al., 1996) and Archean rocks of uncertain cratonic affinity (referred to here as the core zone) in the interior. The latter are locally structurally overlain by Paleoproterozoic shelf-type metasedimentary rocks and intruded by $1.84-1.83 \mathrm{Ga}$ arc-type plutons (e.g., Kuujjuaq and De Pas batholiths; Dunphy and Skulski, 1995; Figure 4). The core zone consists predominantly of Archean gneisses, which in the west are intruded by the ca. $1.83 \mathrm{Ga}$ De Pas (magmatic arc?) batholith, and in the east are overthrust by Paleoproterozoic shelf metasediments and the $1.84-1.83 \mathrm{Ga}$ Lac Lomier complex. This complex is currently viewed as a continuation of the ca. 1.86-1.82 Ga Narsajuaq arc, which is part of the Trans-Hudson Orogen of southern Baffin Island (Scott, 1996; Scott, 1997). It is structurally overlain by the pelitic Tasiuyak gneiss terrane which, together with its charnockitic intrusions, forms the axis of the Torngat orogen, and is interpreted as the remnants of a ca. $1.9 \mathrm{Ga}$ accretionary prism/arc complex. In the northern tip of Labrador, the Tasiuyak gneiss terrane is separated from the Nain craton by the triangular Burwell domain representing the deep levels of a 1.9-1.87 Ga magmatic arc formed on reworked Nain crust in response to eastdipping subduction (Scott and Machado, 1995; Scott, 1995). The structure of the Torngat Orogen is doubly vergent (Figure 5a) with outward verging thrusts and folds centred on the sinistral Abloviak 
(a)

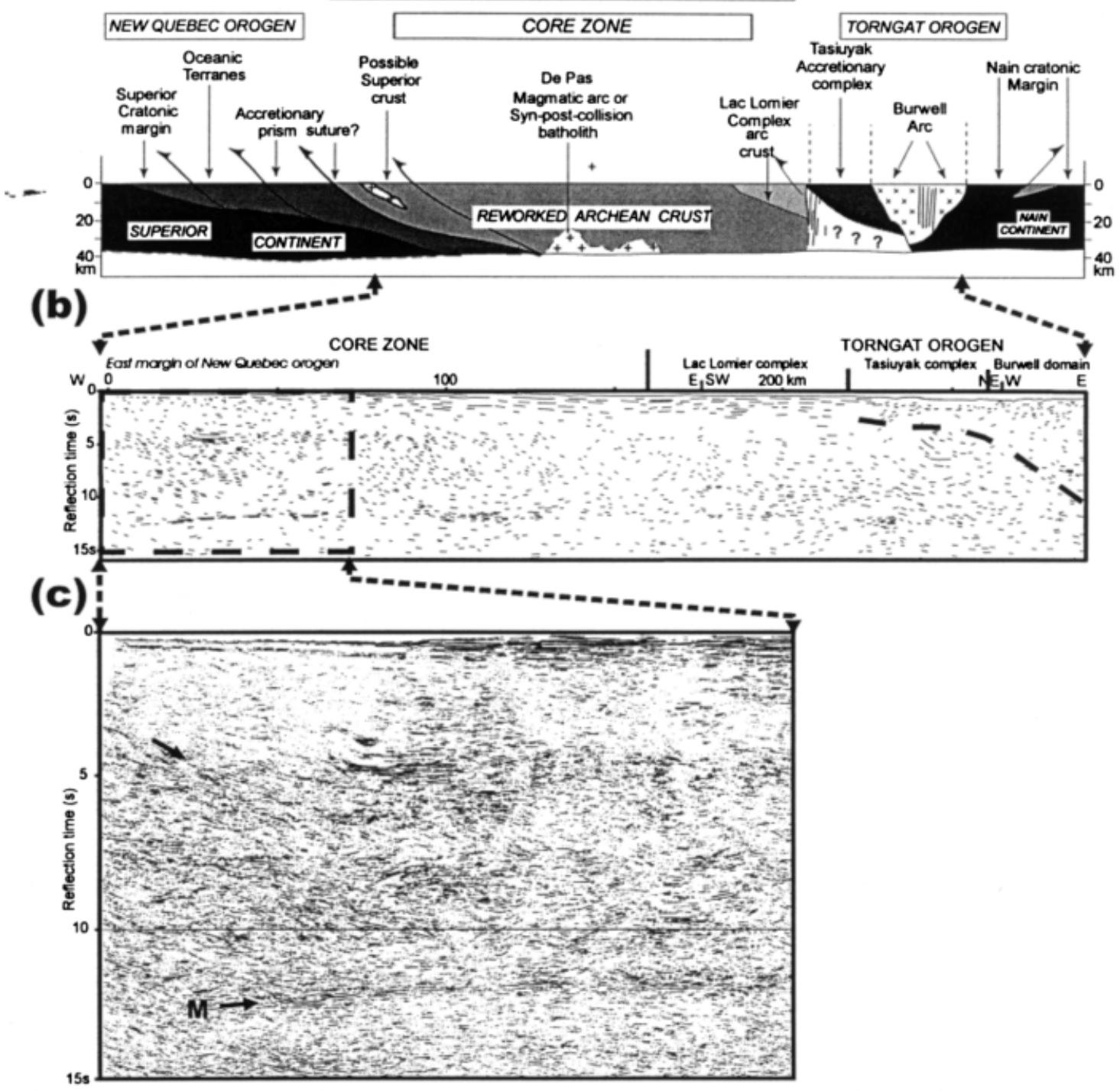

Figure 5 Seismic data for Ungava Bay reflection line across core zone and western Torngat Orogen, Southeastern Churchill Province. (a) Schematic cross-section showing principal tectonic components of the Southeastern Churchill Province (after Wardle and Van Kranendonk, 1996). (b) Line diagram for multichannel reflection seismic line (location on cross-section is shown by arrows; see Figure 4 for location). (c) Panel of migrated seismic reflection data for area shown by the box on the line diagram. $M-$ position of reflection Moho; arrow - east-dipping reflectivity.

shear zone, a wide mylonite belt that is localized within the Tasiuyak gneiss (Figure 4).

\section{Recent results for the Southeastern Churchill Province}

The northern seismic reflection line commenced in the west near the New Quebec Orogen and extended east across the Torngat Orogen and into the northern Nain craton (Figure 4). East-dipping reflectivity pervades the crust of the core zone above a relatively sharply defined reflection Moho (Figure 5). Easterly dips match attitudes of gneissic foliation on the shoreline of Ungava Bay (Bardoux et al., 1996), and are compatible with a general picture of westerly-verging nappes and thrusts.

Seismic data across the Torngat Orogen are of poor quality and do not show clear, discrete reflections or laterally-persistent reflection fabrics. Consequently, interpretation of this area relies largely on field structural data. These reveal a doubly vergent orogen, the axis of which is formed by the lower crustal Tasiuyak gneiss (peak pressures and temperatures being $10-12 \mathrm{~kb}$ at $850^{\circ} \mathrm{C}$ ) bordered by east- and west-verging folds and thrusts that deform the adjacent Nain and core zone Archean blocks. The Tasiuyak gneiss appears to be a juvenile Paleoproterozoic metasedimentary gneiss — charnockite terrane, based on isotopic characteristics (Figure 6; Theriault and Ermanovics, 1997; Scott and Gauthier, 1996), and has been interpreted as an arc/trench complex (Van Kranendonk and Wardle, 1996). A crustal root directly underlying the Torngat orogen (T. Funck et al., personal communication, 1998) may be a consequence of imbrication or duplexing associated with development of the orogen.

The overall west-vergent structural style that dominates the New Quebec Orogen on the west projects through the core zone as far as the Torngat Orogen. The style is interpreted as the result of emplacement of the Nain plate above a lower plate that includes the core zone and the Tasiuyak and Lac Lomier terranes, thus burying the lower plate to mid- and lower crustal depths. This geometry was probably a direct consequence of east-dipping subduction that also would have produced thermal softening of the lower plate, perhaps accounting for the pervasive Paleoproterozoic reworking inferred from reflection fabrics in the generally poor quality data.

The doubly vergent structure of the Torngat Orogen is a composite feature produced by several deformational events that may 
a) TIMS U-Pb GeochronologyTasiuyak gneiss

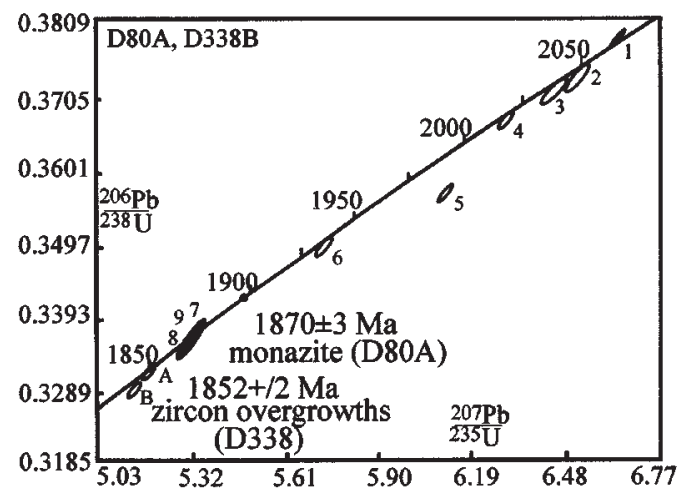

b) LAM-ICP-MS ${ }^{207} \mathrm{~Pb} /{ }^{206} \mathrm{~Pb}$ age dataTasiuyak gneiss
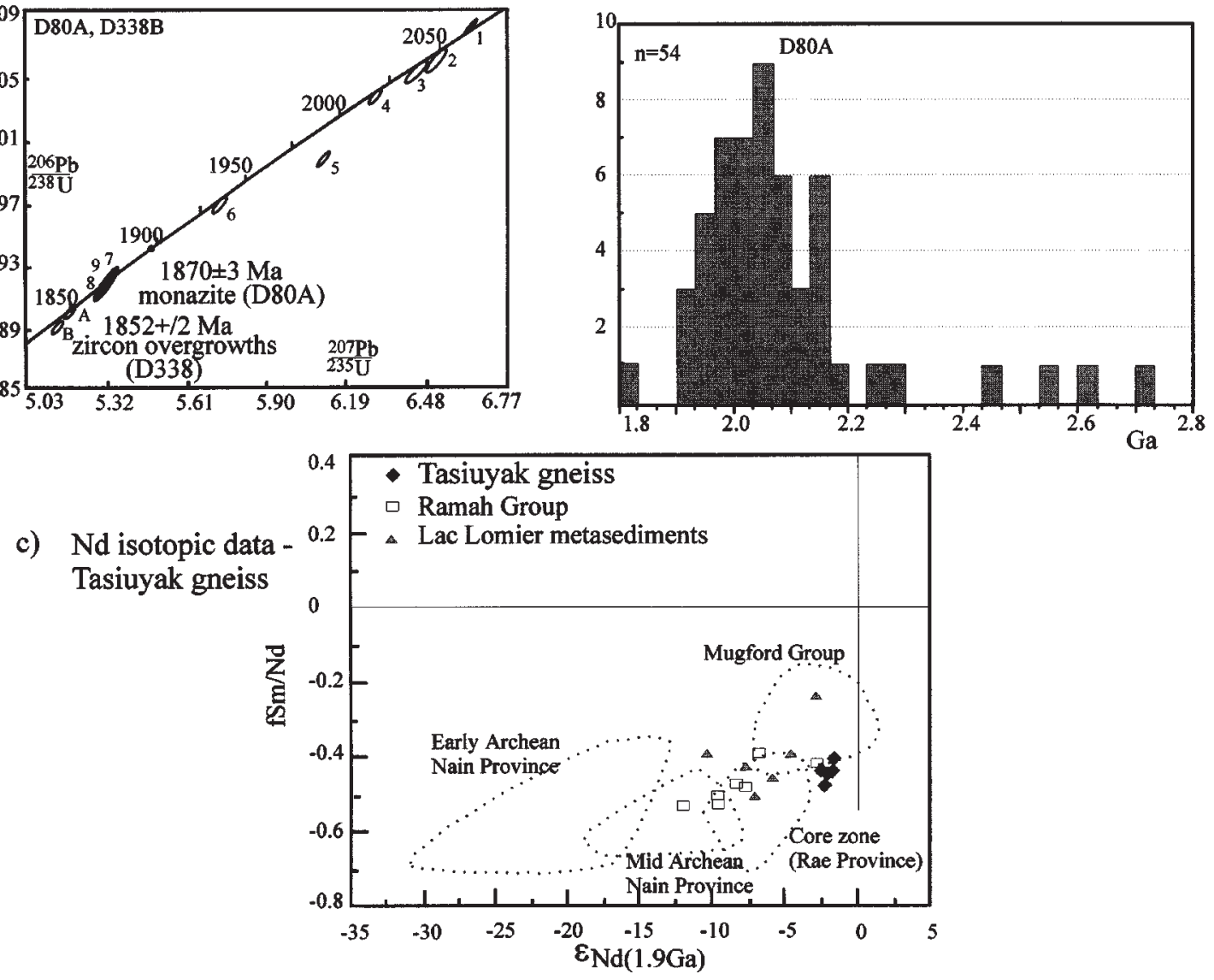

$\mathrm{Ga}$

c) Nd isotopic data - 0.2 Lac Lomier metasediments

Figure 6 Juvenile character of the Tasiuyak gneiss, Torngat Orogen, as displayed by U-Pb geochronology and Sm-Nd isotopic data. (a) Conventional TIMS analyses of individual zircon and monazite crystals. (b) Histogram of LAM-ICP-MS ${ }^{207} \mathrm{~Pb} /{ }^{206 P b}$ age data (Scott and Gauthier, 1996). (c) fSm/Nd vs ENd (1.9 Ga) for Tasiuyak gneiss in comparison with other Paleoproterozoic supracrustal sequences and Archean orthogneisses of the Nain Province and core zone. (After Theriault and Ermanovics, 1997.)

have varied between pure thrusting and pure wrenching over the 120 million year lifespan of the orogen. Thus, Torngat Orogen may give some indication of what the lower crusts of modern transpressional orogens, such as South Island, New Zealand, or the coast range of California might look like. An unresolved problem is the origin of the core zone. Work to date suggests that much of it is an independent Archean block structurally overlain by a wedge of Trans-Hudson orogen juvenile magmatic arc crust (Lac Lomier complex). Whilst the arc crust can be traced north into Baffin Island, where it broadens to form the major Narsajuaq arc (St-Onge et al., 1998), the Archean core zone crust cannot. Thus the core zone is either restricted to the Southeastern Churchill Province, or it plunges under the Narsajuaq arc, possibly accounting for the contaminated Nd isotopic signature of the arc rocks (Theriault, 1998).

\section{Tectonic evolution of Northeastern Laurentia - A working} model

Based on ECSOOT studies, the evolution of the Southeastern Churchill Province in response to the sequential oblique collision of the Nain and Superior cratons is being established in considerable detail (Bertrand et al., 1993; Scott, 1995; Van Kranendonk, 1996; Scott and St-Onge, 1998). More generally, stages in the tectonic evolution of northeastern Laurentia are being developed, as summarized below (Figure 7).

- ca. 2.45-2.1 Ga: Initial rifting led to convergent northward drift of the Superior and Nain continents toward the Archean terranes of the core zone and Disko block to the north.
- ca. $1.91 \mathrm{Ga}$ : Subduction commenced on the northwestern edge of the Nain craton. The Tasiuyak arc/Burwell trench and Narsajuaq arc terranes formed ca. $1.9 \mathrm{Ga}$ as offshore arcltrench complexes.

- ca 1.87-1.85 Ga: Collisions of the Nain block and Tasiuyak-Burwell terrane, and the Nain and Disko blocks occurred, thus forming the Torngat and Nagssugtoqidian orogens, respectively. Development of the Narsajuaq arc in the northeastern TransHudson Orogen commenced ca. $1.86 \mathrm{Ga}$.

- 1.845-1.82 Ga: As a result of continued Nain indentation, strong sinistral shearing took place along the boundary between the core zone and the Tasiuyak-Burwell terrane. Narsajuaq arc magmatism continued in the interval $1.84-1.82 \mathrm{Ga}$ in association with the formation of magmatic arcs (e.g., the De Pas batholith) on the western edge of the core zone. Collision of the Superior Province with the core zone to the east and Narsajuaq arc to the north occurred prior to or at $1.82 \mathrm{Ga}$, thereby forming the New Quebec and Ungava orogens (Cape Smith belt and Baffin segment), respectively. East-dipping fabrics of the core zone, as depicted by seismic data, probably formed during this collision.

- 1.8-1.74 Ga: Continuing post-collisional indentation of the Superior continent to the north, during and following closure of TransHudson Orogen, further developed the Ungava orogen and produced major dextral shear within the core zone. Reactivation of the northern Torngat Orogen involving east-directed thrusting and sinistral shear may have been a far-field response to ca. 1.8 Ga collision in the Makkovik Orogen to the southeast and events in the Trans-Hudson Orogen to the west. 

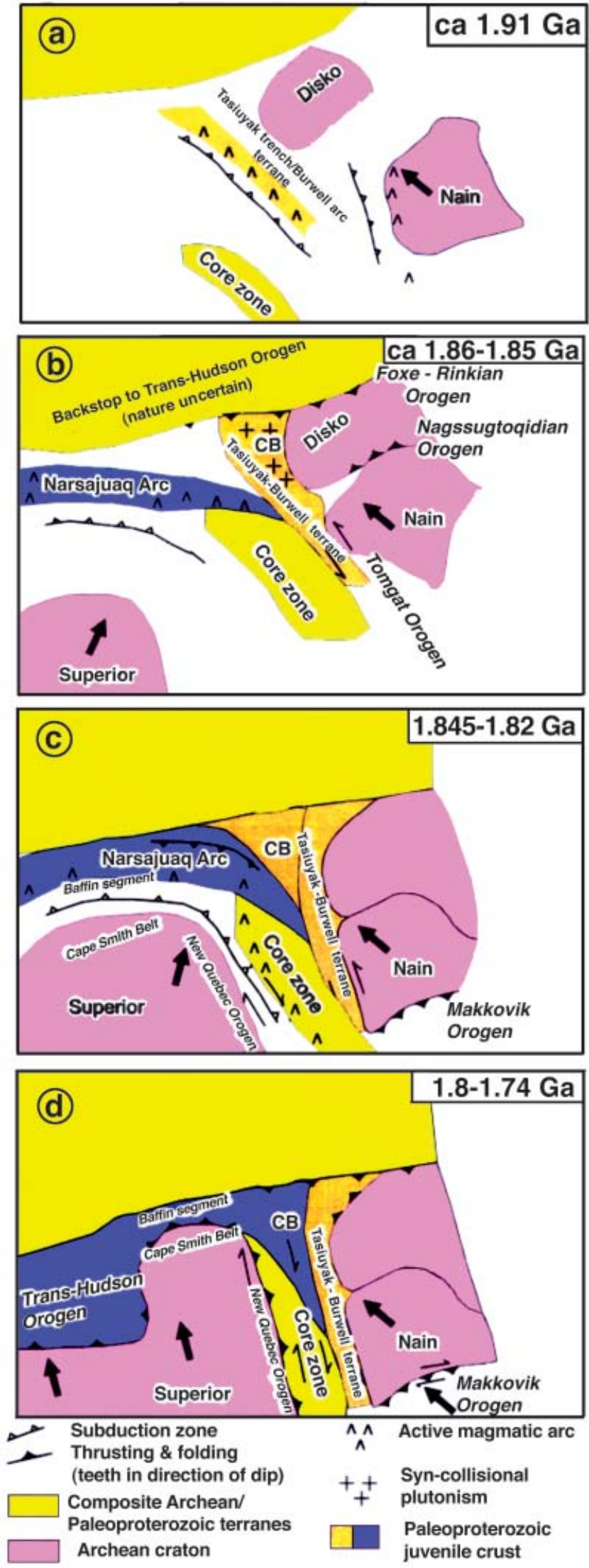

Figure 7 Stages in the Paleoproterozoic evolution of northeastern Laurentia (after Van Kranendonk et al., 1993). See text for discussion.
An important aspect of this study is the recognition that the Southeastern Churchill Province is linked through Baffin Island to the Trans-Hudson Orogen of western Canada, and that there are close similarities in timing of events between these areas. There also appear to be kinematic links, particularly during the final northward drive of the Superior Province to close the Trans-Hudson ocean between 1.8 and $1.74 \mathrm{Ga}$. During this period, sinistral transpression on the western flank of the indenting Superior Province (thousands of kilometers to the west; see Figure 13 below) appears to have been matched by conjugate dextral transpression in the Southeastern Churchill Province on its eastern flank.

\section{A complex continental collision - The Trans- Hudson Orogen}

The core of North America was formed by amalgamation of Archean minicontinents through a network of Paleoproterozoic orogenic belts that involved both reworking of Archean rocks and accretion of juvenile Proterozoic crust (Figure 1). The Paleoproterozoic Trans-Hudson Orogen, the only one which exposes a complete orogenic section, extends from South Dakota, through the exposed Precambrian shield in Saskatchewan-Manitoba, and across Hudson Bay to northern Quebec (Lewry, 1981; Lewry and Stauffer, 1990). Branches may extend through Labrador, central Greenland, and Scandinavia. In Saskatchewan-Manitoba, the study area of LITHOPROBE's TransHudson Orogen Transect (Figure 1), the 500-km-wide orogen includes four major geological elements: a southeast foreland zone, an internal zone (the Reindeer zone) of juvenile Proterozoic crust, an Andean-type magmatic arc batholith, and a northwest hinterland zone (Figure 8). This section presents a sampling of the extensive results achieved to date and their significance for improved understanding of tectonic evolution of the orogen.

\section{Geotectonic background}

The Churchill-Superior Boundary Zone (or Thompson belt) is a narrow southeastern foreland zone of three domains extending along the northwestern margin of the Superior craton (Figure 8). Petrochemistry of volcanic rocks in this zone indicates that they and associated metasediments formed in a rift setting (Baragar and Scoates, 1981). The internal Reindeer Zone (Stauffer, 1984) is a $400 \mathrm{~km}$-wide collage of Paleoproterozoic (ca.1.9-1.8 Ga) arc volcanics, plutons, volcanogenic sediments and younger molasse, divisible into several lithostructural domains. Geochemical and $\mathrm{Nd}$ and $\mathrm{Pb}$ isotopic data indicate that most of these rocks evolved in an oceanic to transitional, subduction-related arc setting, with increasing influence of Archean crustal components to the northwest. The Paleoproterozoic arc terranes were highly deformed and are preserved as refolded nappes and imbricate thrust sheets. Lewry et al. (1990) suggested that juvenile rocks of the internal zone were entirely allochthonous and were tectonically emplaced across reworked Archean lower plate extensions of Superior craton. As discussed below, this suggestion must now be amended. The Wathaman-Chipewyan Batholith, an Andean-type continental margin magmatic arc, was emplaced ca.1855 Ma (Van Schmus et al., 1987; Meyer et al., 1992). This mostly granitic-granodioritic, calc-alkaline plutonic complex is emplaced between reworked Archean continental rocks to the northwest and the accreted arc terranes to the southeast. The northwestern Hinterland Zone includes the Wollaston domain, highly deformed and metamorphosed Paleoproterozoic sediments that are complexly interfolded with Archean rocks; and Cree Lake Zone, a domain that has undergone multiphase Paleoproterozoic deformation and high-grade reworking and is now considered part of the Hearne Province (Hoffman, 1988, 1989).

\section{A newly discovered Archean microcontinent - The Sask Craton}

One critical new result from THOT research is definition and delineation of the "Sask Craton", a newly discovered Archean microcontinental block. Earlier geologic (Lewry et al., 1990) and isotopic (Collerson et al., 1989; Bickford et al., 1990) studies suggested that 
the Reindeer zone was underlain in part by Archean crust, but no information on its extent was available. Initial THOT seismic reflection studies in 1991, followed by additional reflection (1994) and refraction (1993) surveys (locations in Figure 8), delineated the lateral extent of the block (Lucas et al., 1993; Lewry et al., 1994; Hajnal et al., 1996). Significantly, the reflection data show that this Archean lithospheric fragment is structurally isolated from both the Hearne and Superior provinces by imbricated rocks that extend to the base of the crust (e.g., Figure 9). Thus, the Sask craton structurally underlies much of the exposed central Reindeer Zone, continues south below the Phanerozoic cover and probably extends southward beyond the U.S. border as far as North Dakota and Montana (Nelson et al., 1993; Baird et al., 1996). These and related investigations (e.g., Bank et al., 1998) help provide an explanation for the occurrence of a major diamondiferous kimberlite field below the thin Phanerozoic sediments of central Saskatchewan.

The Eastern Reindeer zone - A focus of study

The Reindeer zone of the Trans-Hudson Orogen (THO) has long been considered a type example of juvenile crustal addition and net crustal growth during the Paleoproterozoic (Patchett and Arndt, 1986; Thom et al., 1990). The Flin Flon-Snow Lake (FF-SL) greenstone belts within the zone include substantial metallic mineral resources. For these and other reasons, the Geological Survey of Canada established the National Mapping Program's (NATMAP) Shield Margin Project to focus on the southeastern Reindeer zone and inter-relate directly with THOT activities (Figure 8).

The FF-SL belt is a collage of tectono-stratigraphic assemblages intruded by later plutons and contemporaneously overlain by volcanic and sedimentary rocks (Lucas et al., 1996). Isotopic and geochemical studies have elucidated the nature of the assemblages: juvenile arc, juvenile ocean floor, ocean plateau/ocean island basalt, evolved arc, and rare Archean crustal slices (Figure 10). The terms juvenile and evolved refer to results from $\mathrm{Nd}$ istopic studies (Figure 11). An extensive U-Pb geochronological data base provides information on the crystallization ages of volcanic and plutonic rocks, maximum age of sedimentation, and regional metamorphism, all of which contribute to understanding the tectonic evolution (see below).

Basement geology below the thin Phanerozoic sediments that covers the southern half of the project area (Figure 8) has been delineated through integration of potential field data, shallow drill hole data, and studies on drill hole samples (Figure 12; Leclair et al., 1997). Individual domains identified in the exposed segment are shown to continue below the cover. A major crustal component, the Namew gneiss complex which is generally not exposed, and a previously unknown batholith, the Cormorant batholith, are identified. The combined studies aid interpretation of the seismic reflection data.

Figure 9 shows a composite migrated reflection section and its interpretation across the NATMAP area. The uniform apparent easterly dip of reflection events and the overall high quality of the data are well illustrated. In this region, the Reindeer zone is marked by a northeast-dipping, crustal-scale stack characterized by three principal components which were juxtaposed during 1.84-1.80 Ga collisional deformation: (1) 3.20-2.40 Ga metaplutonic rocks and paragneisses of the Sask craton, exposed as the Sahli granites in the Pelican window (Figure 12b); (2) 1.92-1.87 Ga juvenile arc and oceanic rocks, $1.88-1.84$ Ga plutons, $1.87-1.85$ Ga volcano-sedimentary

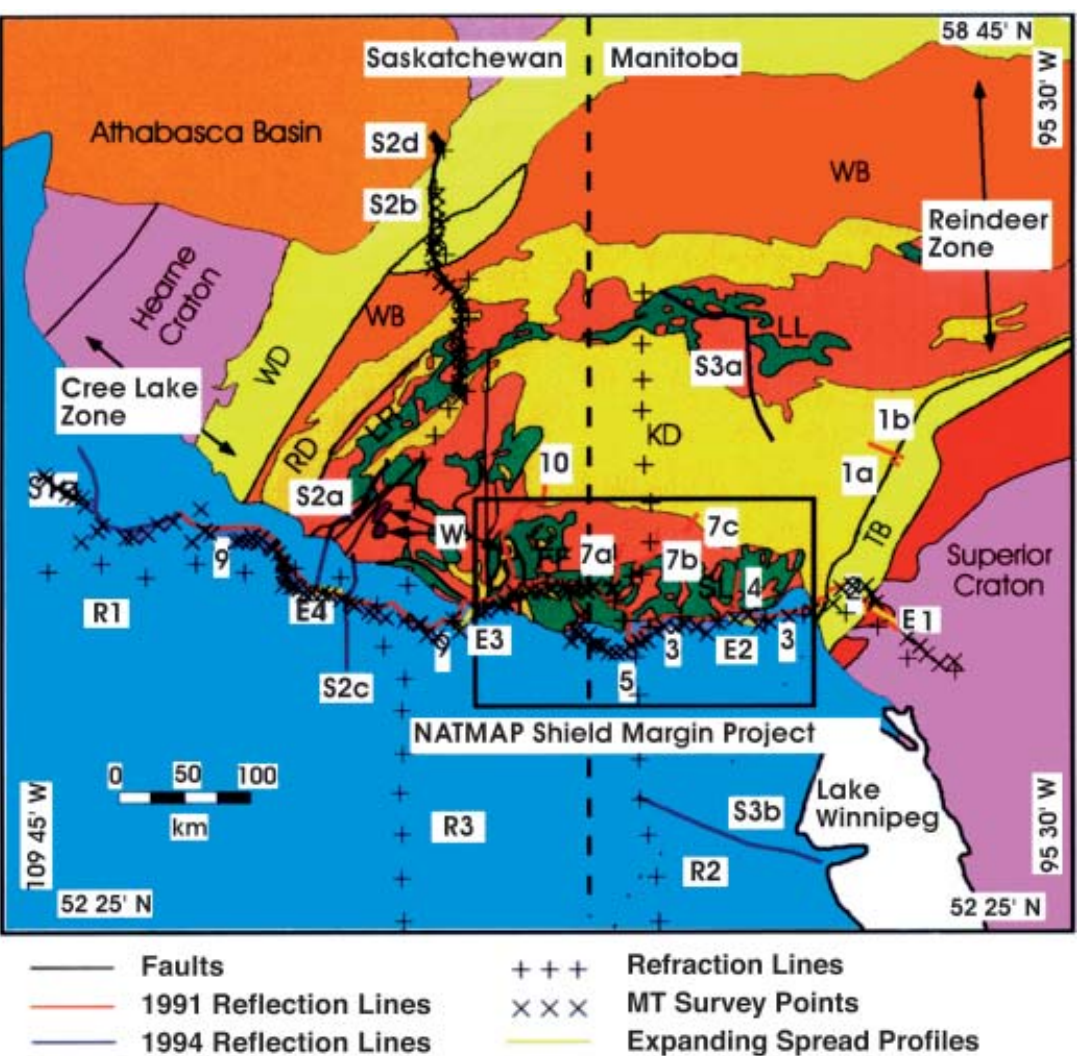

Trans-Hudson Orogen

Sedimentary Rocks

Continental Arc Plutonic Rocks

Marginal Basin/Collisional Sedimentary and Plutonic Rocks

Arc Plutons/Mixed Gneisses

Arc Volcanic and

Plutonic Rocks

Continental Margin Deposits/

Reworked Basement internal domains)

\section{d Trans-Hudson Orogen and}

boundary regions with locations of 1991 and 1994 seismic reflection lines (e.g., 1a, 3, 9, $S 2 a, S 3 b)$, expanding reflection spreads (E1 to E4), seismic refraction profiles (R1, 2 and R3), and magnetotelluric (MT) stations. FF - Flin Flon belt; KD - Kisseyne RD - Rottenstone domain; SL - Snow Lake belt; TB - Thompson belt; W-Archean windows exposed within the Paleoproterozoic domains; WB - Wathaman batholith; WD - Wollaston fold belt. The area of the GSC-Saskatchewan-ManitobaLITHOPROBE Shield Margin NATMAP project is outlined by the box.

packages and 1.85-1.84 Ga alluvial-fluvial sandstones of the Flin Flon-Snow Lake belt; and (3) 1.85-1.84 Ga marine turbidites and distal facies sandstones at the highest structural levels, the Kisseynew Domain (not shown on Figure 9; observed on seismic lines $7 \mathrm{c}$ and 10, Figure 8).

Tectonic evolution of the Trans-Hudson Orogen - A working model

Advances in understanding of Trans-Hudson Orogen (THO) deriving from the integrated LITHOPROBE and NATMAP programs now permit a preliminary synthesis of tectonic evolution of the orogen as summarized below and illustrated in Figure 13.

- ca. 2450-2100 Ma: Pre-rift configuration. Was there a single Kenoran supercontinent with intermittent extension and intracratonic basin development throughout this period, or several inde- 


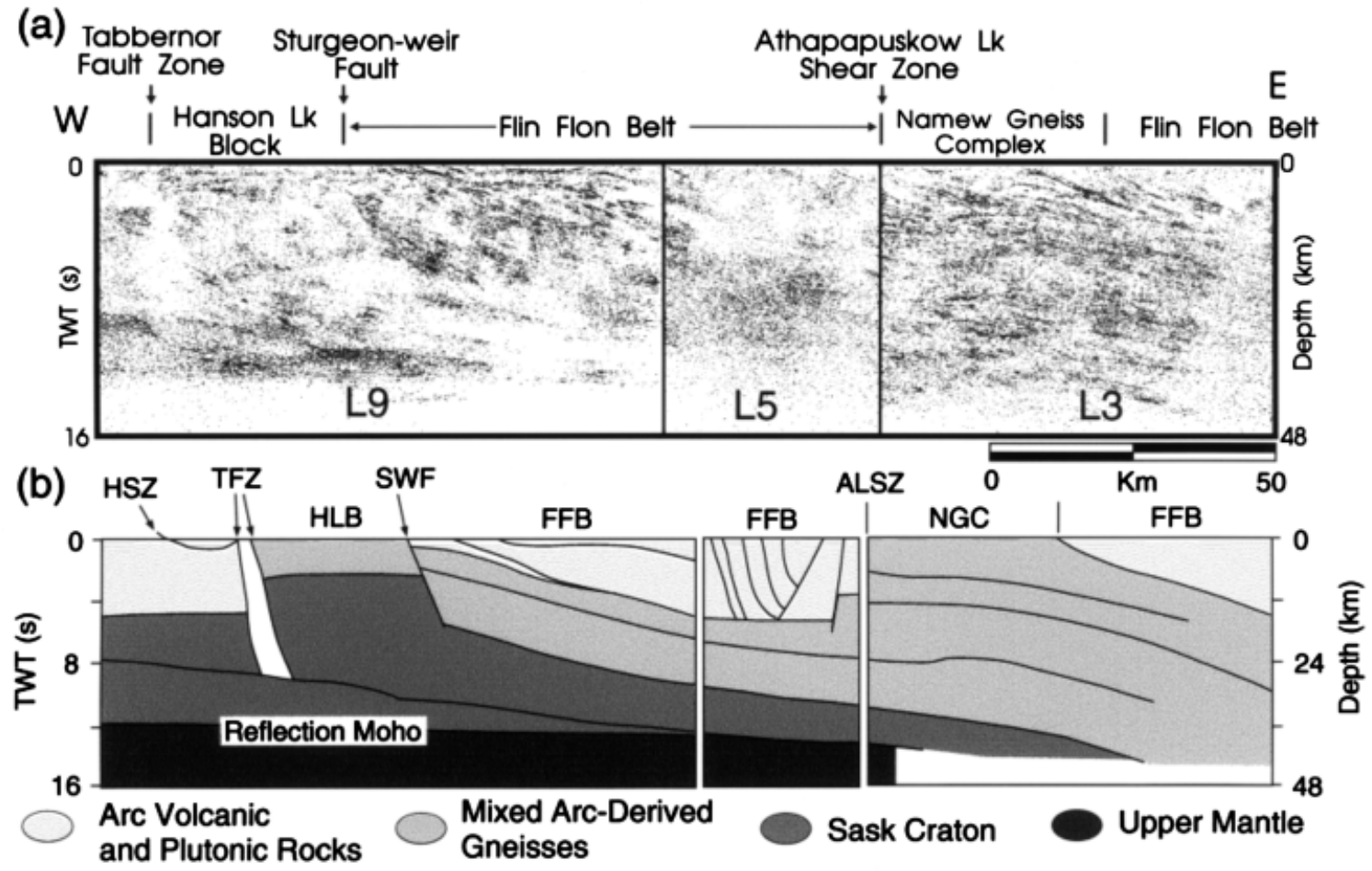

Figure 9 (a) Composite, migrated seismic reflection profile showing the eastern end of line 9, northwestern part of line 5 and western part of line 3 (locations in Figure 8). No vertical exaggeration assuming an average crustal velocity of $6 \mathrm{~km} / \mathrm{s} ;$ hence, all lower crustal depths are underestimated by $\sim 10 \%$ as average crustal velocities are closer to $6.4-6.6 \mathrm{~km} / \mathrm{s}$. (b) Interpretive section for the seismic reflection profiles illustrated in (a). Steeply dipping faults on line 5 are projected to depth from surface along zones of truncated events and/or diffractions. The depth to the inferred Archean basement in the Hanson Lake Block is based on geological projections along line 10 (location in Figure 8). ALSZ - Athapapuskow Lake shear zone; FFB - Flin Flon Belt; HLB - Hanson Lake Block; NGC - Namew Gneiss Complex; SWF - Sturgeon-Weir fault; TFZ - Tabbernor Fault Zone. (Adapted from Lucas et al., 1994.)

pendent minicontinents? Few constraints on pre-2100 Ma arrangement of Archean continental components exist.

- ca. $2100 \mathrm{Ma}$ : Evidence for crustal extension and rifting of Archean continental crust on both sides of the THO. The situation at this time might have been comparable to the present Red Sea-Gulf of Aden area. Over the next 100 to $200 \mathrm{Ma}$, sea-floor spreading produced an ocean comparable to the present-day Atlantic, with deposition of passive-margin sediments along the trailing edges of both the Superior and Rae-Hearne continents.

- ca. 1900-1880 Ma: By about $1900 \mathrm{Ma}$, this developing ocean, which on the basis of paleomagnetic data may have been 5500 $\mathrm{km}$ wide (Symons, 1998), had reached a stage comparable to the present-day Pacific, with subduction of oceanic lithospheric plates and extensive generation of subduction-related, oceanicisland, arc-trench complexes similar to those now seen in the western Pacific.

- ca. 1880-1860 Ma: A number of island arc complexes in the southeastern region had collided with each other and been accreted, together with remnants of intervening oceanic crust, to form a new protocontinental mass which continued to be intruded by 'successor-arc' plutons (Figure 11).

- ca. 1855-1850 Ma: Elements of the La Ronge-Lynn Lake oceanic arc complex(es) collided with, and accreted to, the hitherto passive margin of the Rae-Hearne craton. The Wathaman batholith was intruded as a continental magmatic arc analogous to the modern Andean batholithic belt. Renewed 'back-arc extension' at around this time, comparable to the present-day situation west of the Philippines and north of Indonesia, may have initiated the Kisseynew sedimentary basin.

- ca. 1850-1840 Ma: Earlier collisional orogenic events had resulted in major uplift and ongoing erosion of cordilleran highlands and successor volcanic island arc complexes. Sediments derived from such erosion included both material being deposited in the now well developed marine Kisseynew basin and also more continental to fluvial 'molasse' deposits of the Missi and similar groups throughout central parts of the orogen. The situation at this stage may have been comparable to early stages in development of the present-day Mediterranean.

- ca. 1835-1830 Ma: Complex plate motions and subduction resulted in arrival of a small Archean microcontinent, the Sask craton, from the southwest. This microcontinent collided with the previously developed, juvenile, volcanic protocontinent, the collision initiating major orogenic shortening and crustal thickening in central parts of the developing THO. Tectonic shortening and collapse of the Kisseynew basin also began.

- ca. 1820 Ma: Orogenic closure and destruction of a 'Mediterranean-type' oceanic tract was essentially completed with arrival of the larger Superior continental plate from the south or southeast. Initial folding and overthrusting along the Superior margin, presumed to mark such ongoing terminal collision, was probably underway. Major crustal imbrication and thickening within the central zone of the orogen was probably reaching its peak.

- ca. 1800 Ma: Himalayan-type, terminal orogenic closure was probably almost complete. The metamorphic thermal peak occurred sometime between 1820 and $1800 \mathrm{Ma}$, and by this time a collisional mountain belt comparable in lateral extent to the present-day Himalayas probably extended through Saskatchewan and Manitoba and across the Hudson Bay area toward Greenland. Continuing oblique convergence of the Superior continental plate produced several phases of deformation. Terminal collision of the Superior plate may have produced some 'oroclinal' rotation of the southern part of the Rae-Hearne continental block, in a 
(A)

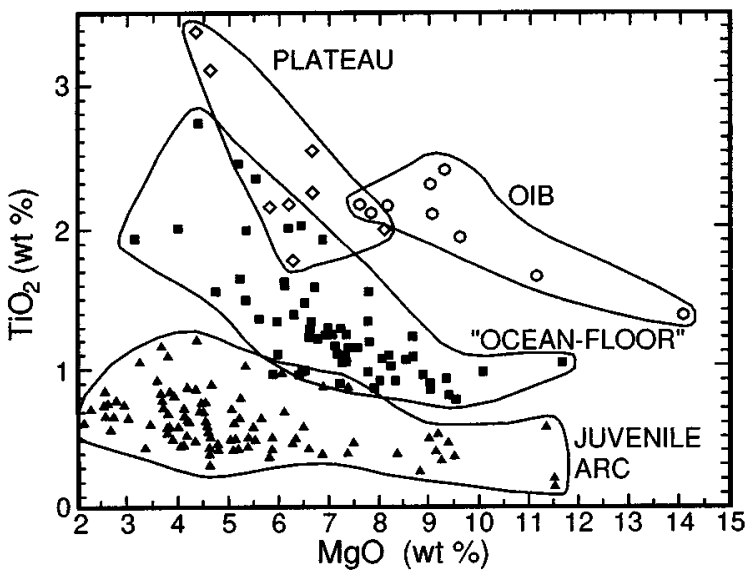

(B)

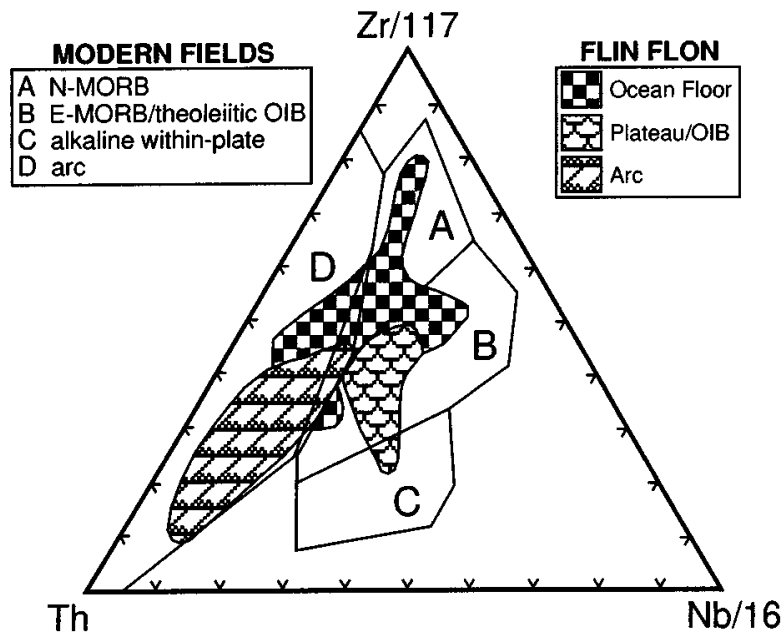

Figure 10 (a) Geochemical and isotopic evidence for distinct 1.92-1.88 Ga tectono-stratigraphic assemblages in the Flin Flon Belt: $\mathrm{TiO}_{2}$ versus $\mathrm{MgO}$ plot showing data for mafic volcanic rocks from the NATMAP study area. Mafic rocks are grouped by assemblage type (juvenile arc, ocean floor, oceanic plateau, ocean island basalt). Data from Stern et al. (1995a, 1995b). (b) Comparison of trace element geochemistry of central Flin Flon Belt basalts with modern basalts: $\mathrm{Zr}$-Th-Nb plot with fields for modern basalts from Wood (1980). Fields for Flin Flon Belt basalts derived from data in Stern et al. (1995a, 1995b). (Adapted from Lucas et al., 1996.)

manner analogous to rotation of parts of Pakistan due to indentation of the colliding Indian plate in the northwestern Himalayas.

- ca. 1800-1700 Ma: The Trans-Hudson orogenic belt underwent internal faulting and other declining deformational adjustments, continued isostatic uplift, and erosion and cooling. Isotopic evidence indicates that late, post-orogenic granite and pegmatites, intruded at about 1770 to $1780 \mathrm{Ma}$ in central parts of the orogen, were derived in part from remelting of ancient Archean crust of the previously underthrust Sask craton. Gold mineralization seems to have been emplaced under cooling, brittle-ductile crustal conditions at about 1720 to $1700 \mathrm{Ma}$.

\section{The Canadian Cordillera - Westward growth of North America}

The structure and growth of Mesozoic western North America within Canada has been the focus of LITHOPROBE's Southern Cordillera transect since the initiation of the project. A great deal of new information has been gathered; results are summarized in a special journal issue (Cook, 1995). In this section, only a few principal results are described.

\section{Geotectonic background}

The Cordillera of western North America is one of the great mountain systems of the world. The Canadian Cordillera (Figure 14) was one of the orogens in which terranes were first recognized as fundamental building blocks of the continent (Coney et al., 1980; Monger et al., 1982). The principal stages in its formation involve Paleoproterozoic to Recent tectonic processes (Gabrielse and Yorath, 1991; Monger et al., 1994) that occurred on, and adjacent to, the foundation of Late Archean to Paleoproterozoic crystalline rocks of the Canadian Shield. This basement was rifted during at least three periods of extension, in Meso- and Neoproterozoic and early Paleozoic times.

Orogenic activity spans the time interval from Devonian, when extensive volcanism and plutonism took place west of the passive margin, to Eocene. Major compressional events occurred between the Middle Jurassic and Paleocene (170-60 Ma), as extensive terrranes composed of Paleozoic and younger intraoceanic-arc and ocean-floor rocks were accreted to the margin. Between 100 and 40 $\mathrm{Ma}$, large, right-lateral strike-slip faults that partly accommodated northward motion of the terranes relative to North America formed in the western part of the Cordillera. At about $58 \mathrm{Ma}$, tectonism in the southern Cordillera underwent a fundamental transition from east-west shortening and crustal thickening to east-west stretching and crustal thinning, these being associated with widespread magmatic-arc activity and exposure of metamorphic core complexes. Since the Eocene extension, the interior of the Cordillera has been relatively quiescent, whereas the western margin has undergone subduction-related magmatism producing the Cascades and GaribaldiPemberton volcanic belts. East-dipping subduction of the Juan de Fuca plate continues today off the west coast.

\section{A lithospheric cross-section of the Southern Canadian Cordillera}

Figure 15 illustrates some of the principal results from the Southern Cordillera transect, although the cross-section does not indicate the extensive three-dimensional variations that are fundamental to the formation of the mountain belt (e.g., Wheeler and McFeely, 1991; Clowes et al., 1995; Jones and Gough, 1995). One of the key results is that rocks observed on the surface are decoupled from the mantle and, in some cases, the crust upon which they were formed, and attached as thin flakes, or sheets, to the craton. In the east, the decoupling surface (decollement) steps downward from the front of the Foreland thrust and fold belt to the middle crust beneath the western Purcell Mountains and Omineca belt (Cook et al., 1992). In the western Omineca belt and Intermontane belt, it penetrates to the lower crust, and perhaps even to the Moho. Above the decollement in these regions, crustal-scale imbrication and antiforms were generated by collisional tectonics. The concept of allochthons, thin relative to both across-strike and along-strike dimensions, was confirmed in these LITHOPROBE studies. As nearly 13,000 km of Pacific ocean plates converged with western North America since the Jurassic (Engebretson et al., 1992), most of their lithosphere was subducted, leaving only the upper part to contribute to the $500 \mathrm{~km}$ of westward growth of the continent. What has happened to the subducted lithosphere is a key question requiring further research.

Post-orogenic Paleocene-Eocene extension has provided a series of "windows" into the deep crust (core complexes) that have exposed the older accretionary relationships. Remnants of middle and lower crustal structural, igneous, and metamorphic features are visible in these complexes and can be tied to results from the deep geophysical surveys. Perhaps the best studied ones are the Monashee and Valhalla complexes (e.g., Carr, 1995), where three crustal levels are exposed. The lower level includes North American Precambrian basement (1.8-2.1 Ga) and metasedimentary cover rocks. The middle level comprises metasedimentary rocks whose original sediments were deposited near the North American margin. Upper level rocks are preserved only in the hanging walls of the regional extensional faults and may be associated with the accreted terranes. This basic picture, augmented by geometric information on crustal struc- 


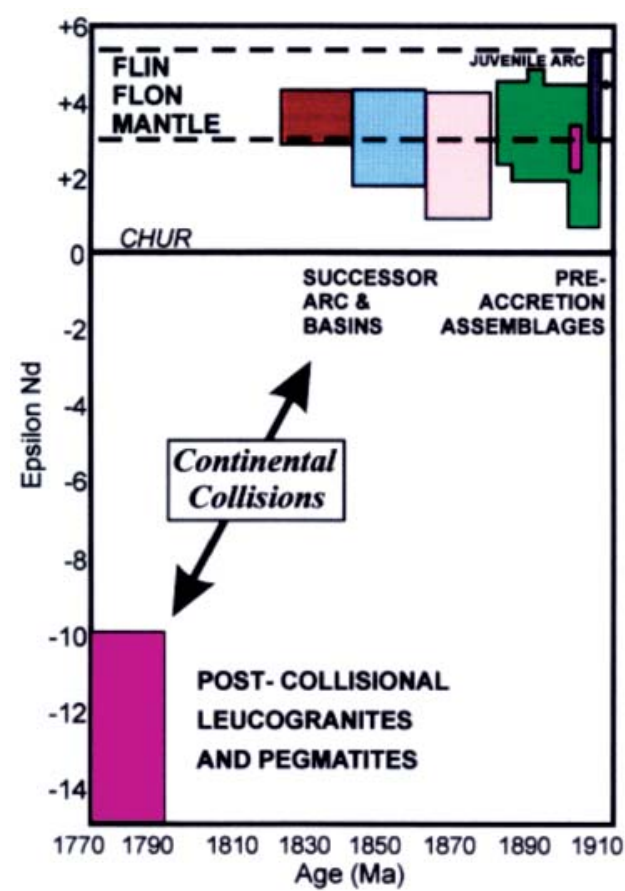

Figure 11 Epsilon Nd versus time diagram for units in the eastern Reindeer zone showing that 1.9-1.83 Ga volcanic and plutonic rocks are juvenile, consistent with intraoceanic arc and back-arc settings with little to no involvement of older crustal material (Stern et al., 1995a,b; Lucas et al., 1996). In contrast, post$1.80 \mathrm{Ga}$ (i.e., post-collision) pegmatites and leucogranites throughout the Flin Flon-Snow Lake complex yield Nd model ages and feldspar $\mathrm{Pb}$ isotopic signatures which indicate partial to complete derivation from remelting of Archean basement (Bickford et al., 1990, 1992). ture from seismic reflection (Cook et al., 1992) and refraction (Clowes et al., 1995) data and by isotopic studies of magmatic rocks (Ghosh, 1995), indicates that the cratonic lower crust (NA, Figure 15) and Precambrian upper mantle are present beneath the Intermontane Belt as far west as the Fraser strikeslip fault.

In the Intermontane belt and east of it, the prevalent tectonic deformation is east vergent. In contrast, deformation in the Coast and Insular belts is dominantly west vergent (Figure 15). The eastern Coast belt comprises a thrust system which resulted from late Cretaceous shortening and involved accreted terranes (Journeay and Friedman, 1993). Geophysical studies indicate a small associated crustal root. The western Coast belt is dominated by plutonic rocks which are derived primarily from a depleted mantle source with little or no interaction with evolved continental material (Friedman et al., 1995). On the basis of seismically constrained gravity interpretations (Clowes et al., 1997), the plutons comprise a low density layer, up to $30 \mathrm{~km}$ thick, underlain by a higher density layer less than $10 \mathrm{~km}$ thick ("mafic residue", Figure 15). Given that plutonism was a prolonged, episodic process which both predated and postdated convergence of the Insular and Intermontane superterranes, one explanation for this layering is fractionation accompanying magma generation from arc-derived lower crust and (or) mantle. Lighter components formed the majority of the crust, whereas heavier ones were left as a layer at the base. Alternatively, widespread under-

(a)

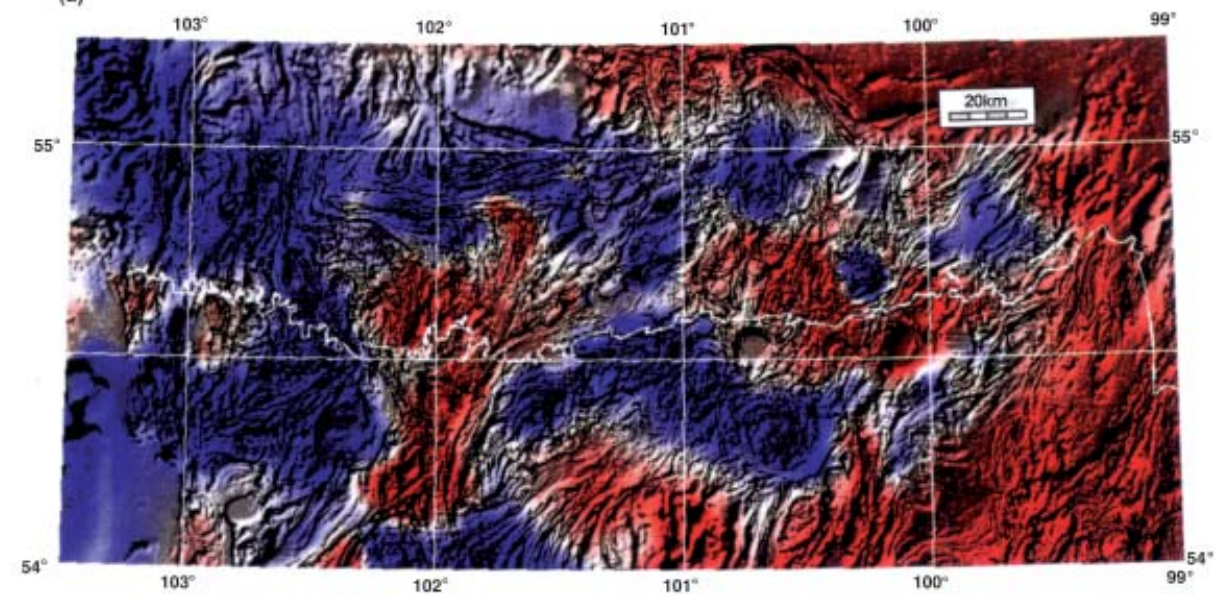

Figure 12 (a) Composite potential field image generated from gridded aeromagnetic and gravity data. The gray-tone shaded-relief image was generated by simulated illumination of the aeromagnetic data from the southeast at an inclination of $40^{\circ}$ from horizontal. The magenta/cyan hue of the image is indicative of high/low intensity in the Bouguer gravity field. White line indicates the trace of the Precambrian-Phanerozoic contact (shield margin). (b) Major lithotectonic domains and regional tectonic framework of the exposed and buried Flin Flon belt derived from potential field maps, correlations with exposed geology (region north of the white line), shallow drillhole data, and studies on drillhole samples. Some faults are identified by letter abbreviations. (Adapted from Leclair et al., 1997.) 


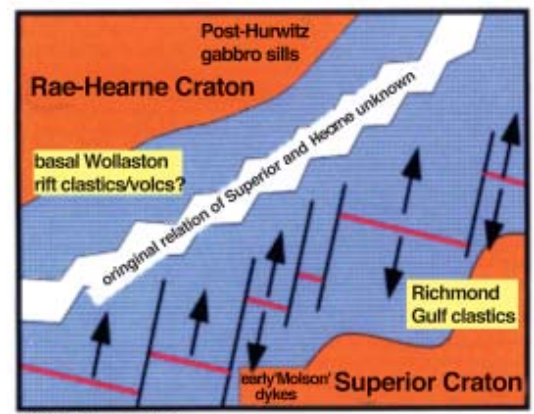

\section{$2100 \mathrm{Ma}$}

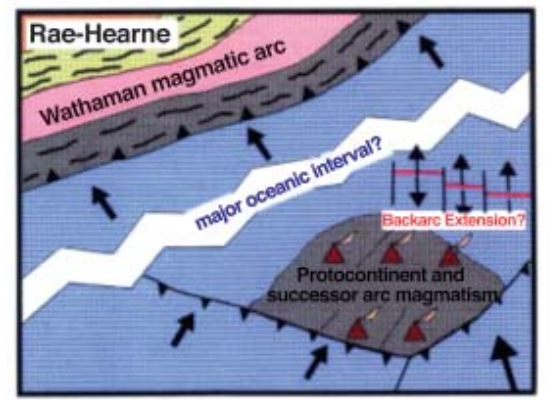

1855-1850 Ma

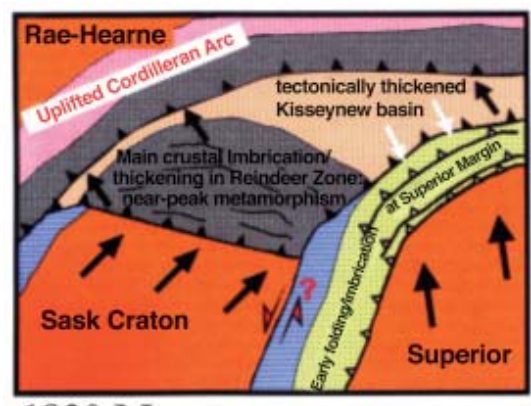

$1820 \mathrm{Ma}$

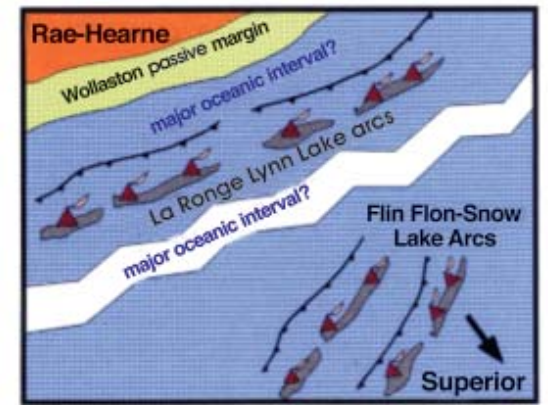

1900-1880 Ma

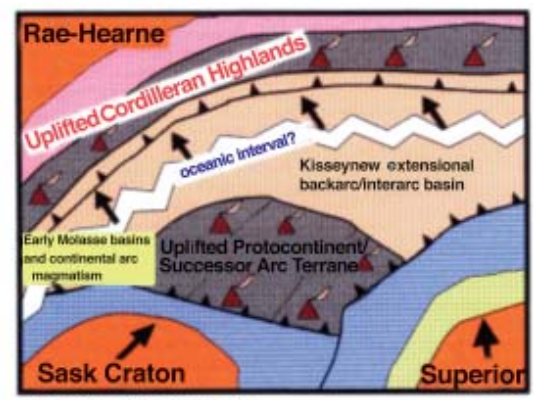

1850-1840 Мa

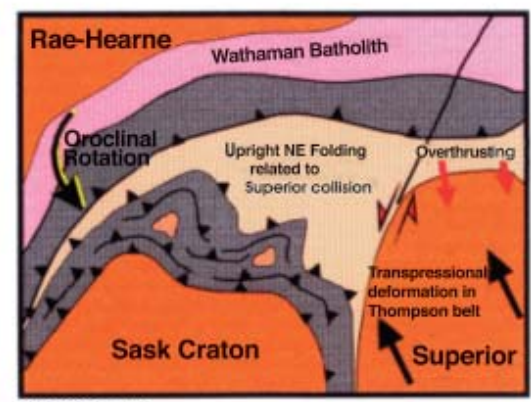

$1800 \mathrm{Ma}$

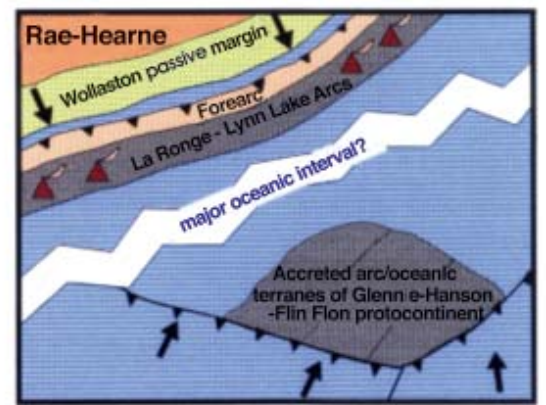

1870-1860 Ma

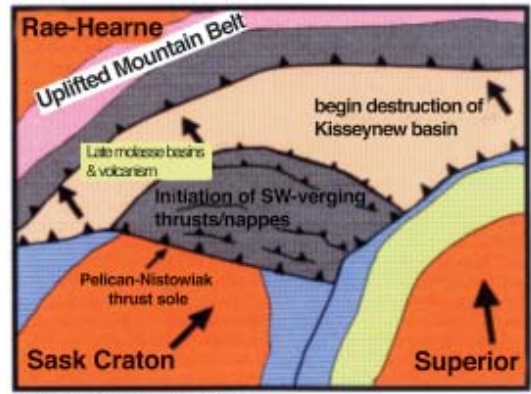

1835-1830 Мa

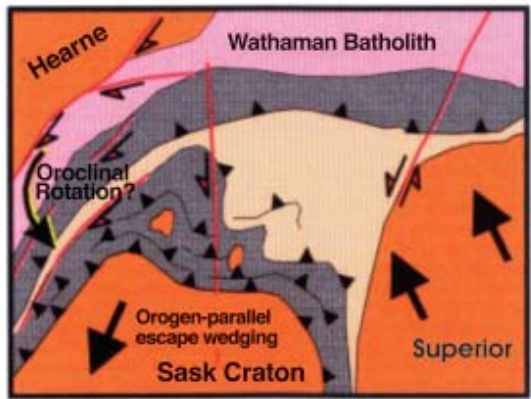

$1780 \mathrm{Ma}$

Figure 13 Working model for the tectonic evolution of the Trans-Hudson Orogen for the period 2100 Ma to 1780 Ma. See text for discussion.

plating associated with the subduction regime along western North America also could have generated the interpreted high-density, strongly mafic layer.

The first major LITHOPROBE surveys, and the first across an ocean-continent subduction zone, were recorded on Vancouver Island and provided key insight into mechanisms of the accretion process (Green et al., 1986; Clowes et al., 1987; Hyndman et al., 1990). Two subparallel, prominent reflectors are situated structurally above the subducting Juan de Fuca plate, the lower one characterized by high electrical conductivity (probably fluid-filled layers; Kurtz et al., 1990). These reflectors bound a zone of high seismic velocity (Drew and Clowes, 1990) and are interpreted as delineating a slice of material that was detached from the subducting plate and added to the base of the accretionary complex beneath Vancouver Island (Figure 15). Results from these studies demonstrate that accretion at a young plate boundary is characterized by near-surface thrusting (accretionary wedge) and crustal-scale, subsurface duplexing analogous to that seen in fold and thrust belts. The LITHOPROBE studies combined with extensive follow-up research by the Geological Survey of Canada are leading to a better understanding of the megathrust earthquake cycle and the hazards associated with the Cascadia subduction zone (e.g., Hyndman and Wang, 1996).

Seismic wide-angle reflection data identify shallow mantle reflectors which are interpreted to be from the top of a shallow asthenosphere (Figure 15; Clowes et al., 1995), consistent with interpretations from earlier surface wave and geomagnetic studies. Below the central Coast belt, warm low-velocity material of the shal- low asthenosphere must interact in some manner with the cold oceanic lithosphere of the subducting Juan de Fuca plate. Bostock and VanDecar (1995) suggest that the angle of descent of the subducting plate steepens to $50-60^{\circ}$ (approximately below the Garibaldi volcanic belt) (Figure 15). In this scenario, the mantle region below the central Coast belt is the locus of a "sink" for both the subducting lithosphere and the western limb of the mantle upwelling below the Intermontane and Omineca belts, as proposed by Gough (1986). The asthenosphere in the "sink" is cooled by, and becomes accreted to, the subducting slab, thereby increasing the size of the mechanically defined lithosphere and providing a mechanism for driving convective flow in the shallow asthenosphere (Davis and Lewis, 1984).

\section{The future - Toward a pan- LITHOPROBE synthesis}

Each of the ten transect teams (Figure 1) will develop a synthesis of results from their multidisciplinary scientific programs. Three of these syntheses have been completed: GLIMPCE (Gibb et al., 1994), Kapuskasing Structural Zone (Percival, 1994), and Southern Cordillera (Cook, 1995). The Abitibi-Grenville Transect has published three regional syntheses (Boerner et al., 1994; Ludden, 1994, 1995), with a final overview in preparation. Synthesis of the LITHOPROBE East Transect is in the final phase of manuscript preparation. Three other transects, THOT, Alberta Basement, and ECSOOT, 


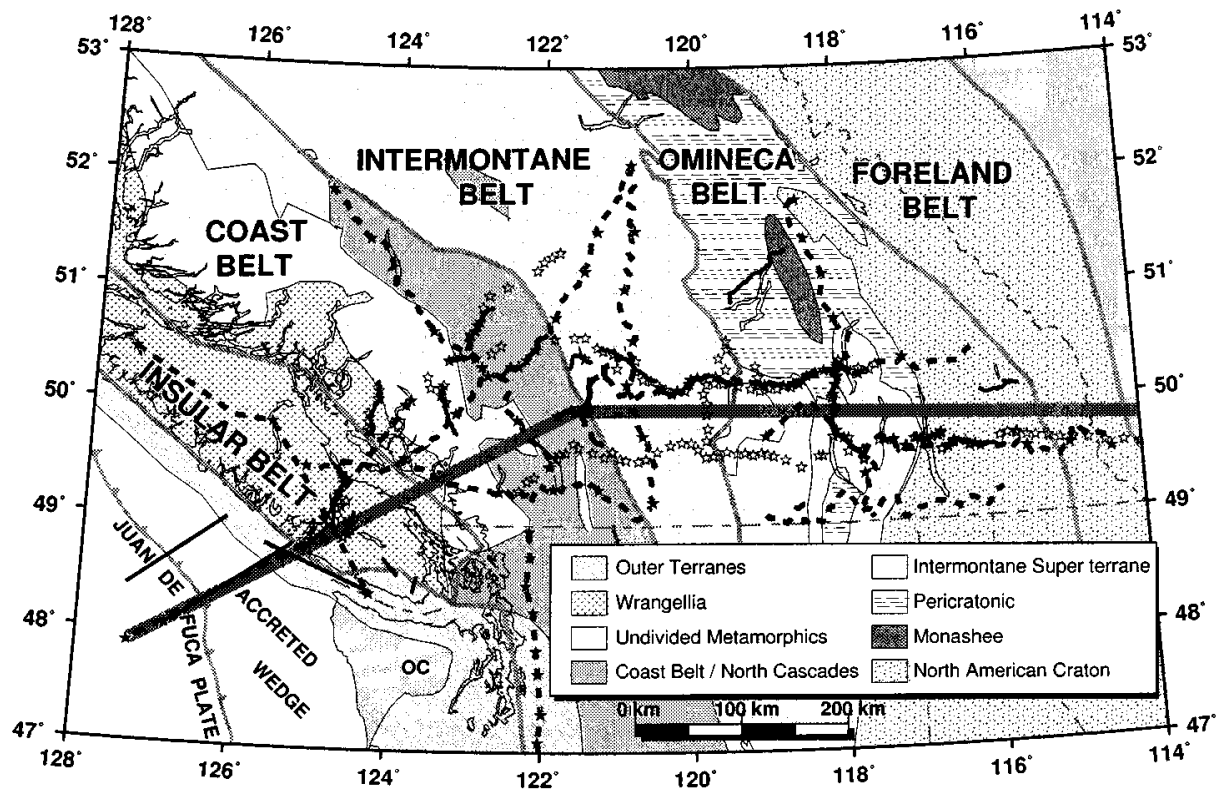

Figure 14 Map of the southern Canadian Cordillera showing the major tectonic units, morphogeological belts, and principal terrane elements. In this simplified map, "North American Craton" region includes the Proterozoic Belt-Purcell and Windermere metasedimentary supergroups; "Pericratonic" includes the Kootenay terrane; "Intermontane superterrane" includes Quesnellia, Stikinia, and Cache Creek terranes; "Coast belt - N. Cascades" region includes Cadwallader and Bridge River terranes; $O C$ is the core of the Olympic Mountains, an exposed part of the accreted wedge. Seismic reflection profiles are indicated by heavy solid lines. Seismic refraction - wide-angle reflection profiles, with shot points indicated by stars, are shown as dashed lines; profiles along Vancouver Island, offshore, across the island, and in Washington are not LITHOPROBE lines but were used in an areal compilation. Magnetotelluric station sites are shown by asterisks. Broad grey line shows location of cross-section in Figure 15.

have continuing analyses and interpretations to complete before syntheses can be compiled. Chronologically, the two final transects, Western Superior and SNORCLE, still have 2 years of data acquisition and subsequent interpretations to complete before LITHOPROBE is brought to a conclusion (Figure 2).

The final scientific component of the project will be a panLITHOPROBE synthesis. Integration and synthesis of the comprehensive, multidisciplinary results from all ten transects, which collectively will illustrate tectonic evolution and processes operative during most stages of Earth history, is an opportunity that no other earth science project has had. The only similar undertaking, and an excellent example, is the synthesis of the European Geotraverse project (Blundell et al., 1992).

"Pan-LITHOPROBE synthesis" refers to a spectrum of related activities, notably: (1) presentation of data and results for the landmass and offshore margins of Canada; (2) lithospheric cross-sections, one extending for more than $5000 \mathrm{~km}$ from the Pacific Ocean to the Labrador Sea (Figure 15 represents a start on this); (3) reconstruction of geometrical and kinematic evolution of the tectonic elements of northern North America; (4) investigations of the nature and mechanisms of the tectonic processes associated with lithospheric evolution, including geodynamic modeling; and (5) comparison of LITHOPROBE results with those from similar studies worldwide. By the time of the formal completion of LITHOPROBE in 2003 , the enhanced understanding of the present configuration and structure of the diverse tectonic elements that form Canada, and of the tectonic processes that created the continent, should provide a novel and unique contribution to the earth sciences and further stimulus, perhaps, to undertaking comparable investigations in other continents.

\section{A LITHOPROBE legacy - Benefits to Canada and the world}

The most lasting legacy that any scientific project can have is rooted in both the quality of the scientific results and their value to humanity. LITHOPROBE results are being used to establish the architecture and tectonic evolution of the North American continent. This provides basic information for activities such as finding and managing resources, predicting and mitigating hazards (e.g., earthquakes, volcanic eruptions), and establishing how earth processes formed continents as long as three billion years ago and as recently as today. These exciting and informative results are being brought to the attention of the public through an outreach strategy involving the media, educational institutions and other targeted groups.

On a pragmatic level, LITHOPROBE studies have provided a focus for activities in the Canadian earth science community for more than a decade. The quality results are the "glue" that keeps the network and partnerships together, even expanding, and the LITHOPROBE structure is the mechanism that facilitates the essential interactions. LITHOPROBE developments and results have provided substantial contributions to Canada's resource-based industries. For the Canadian earth science community, and for Canada as a country, LITHOPROBE is, and has been, more than a successful scientific project: it has brought wide-ranging benefits to Canada, as noted below. As such, LITHOPROBE may serve as a model for similar projects elsewhere in the world.

- Regional information for industry. The new and improved understanding of Earth history in regions that are amenable to resource exploration provides petroleum and mining companies with an enhanced knowledge base from which their own more detailed exploration and development plans can be prepared. In the Western Canada Sedimentary Basin, the first continuous seismic reflection profile across the entire basin, recorded with similar state-of-the-art acquisition parameters, is being compiled. In a variety of mining locations associated with base metals, diamonds and uranium throughout Canada, LITHOPROBE's studies provide a valuable framework of knowledge and understanding that otherwise would not exist.

- Technological innovation and transfer of science and technology to the private sector. LITHOPROBE has demonstrated the applicability of the high resolution seismic reflection technique to mineral exploration problems, particularly in mining regions where expensive infrastructure is already in place (e.g., Clowes, 1994). Now a number of companies are proceeding with their own seismic programs, including the use of 3-D procedures (e.g., Eaton et al., 1997). The Geological Survey of Canada's (GSC) involvement in LITHOPROBE has spawned a major new geophysical program in the application of combined seismic, EM, and rock properties techniques to mining camps, with the aim of directly detecting orebodies. This program, continuing in partnership with industry, is an outgrowth of LITHOPROBE's scientific studies and integrative philosophy. 

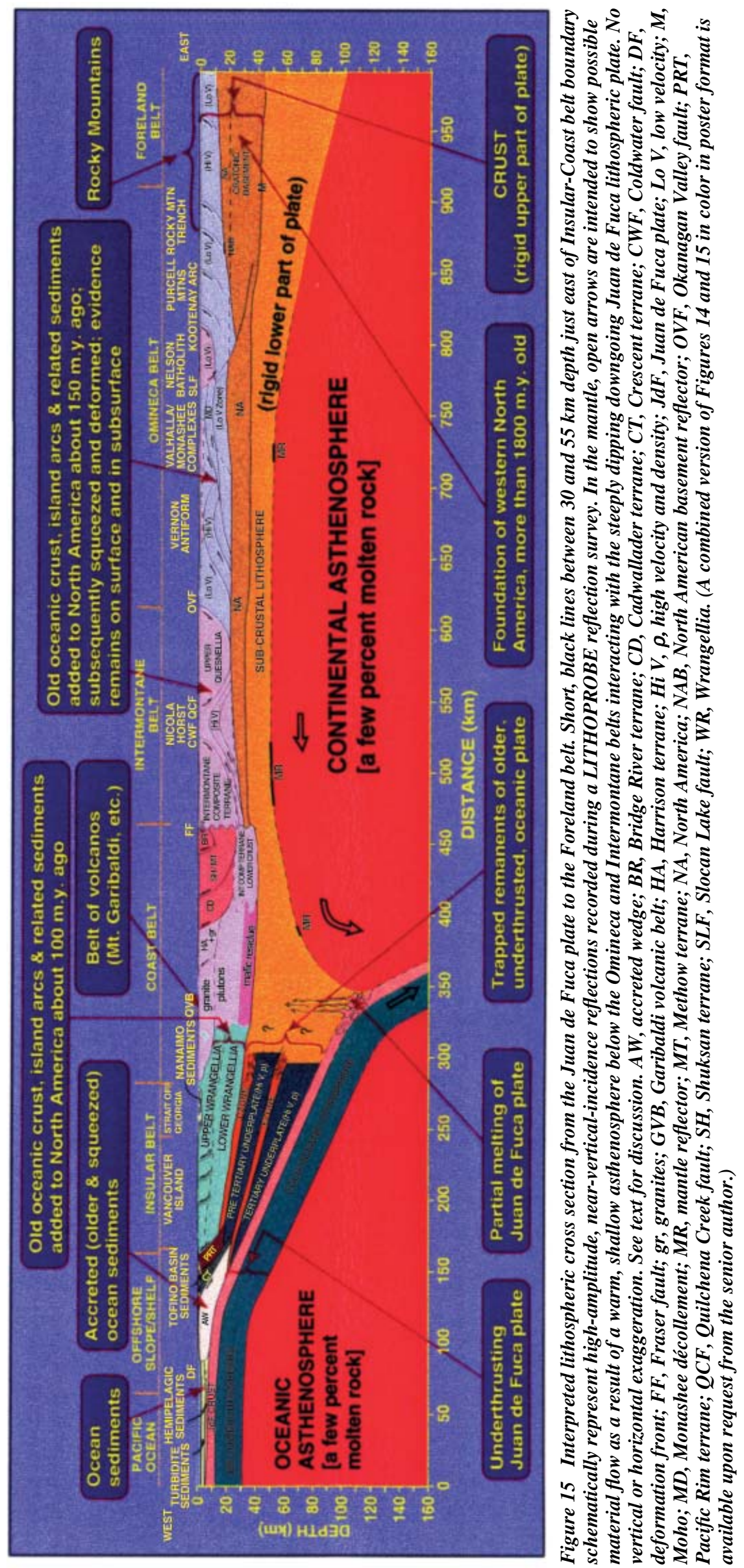

LITHOPROBE seismologists designed a new portable seismic refraction seismograph in the mid-1980s. GSC personnel developed and tested the instrument. The technology was transferred to Scintrex, Ltd., a major Canadian geophysical company which has made significant sales worldwide. GSC scientists active in LITHOPROBE designed and built a new magnetotelluric (MT) instrument and then developed a special long-period version. The resultant technology has been transferred to Phoenix Geophysics which specializes in MT work, and has further developed the instruments. Cooperation with the GSC at the research level continues. On a worldwide basis, Phoenix sells the instruments and carries out contract surveys using them. In their field, they are probably the pre-eminent company in the world, partly through their association with LITHOPROBE.

- New resources and mitigation of hazards. During the past few years, LITHOPROBE data and interpretations in the LITHOPROBE East Transect have contributed to a petroleum discovery on the west coast of Newfoundland. As a result of LITHOPROBE and related studies, new exploration possibilities for the delineation of ore bodies have been established in the Sudbury region (Abitibi-Grenville Transect), in Saskatchewan (THOT) and in New Brunswick. Very high resolution seismic reflection studies, applied first by LITHOPROBE and now being refined in the private sector, are identifying new sub-basins and faults associated with uranium deposits in northern Saskatchewan.

LITHOPROBE studies on the west coast of Canada, as part of the Southern Cordillera Transect, provided data and a framework for better understanding the mega-thrust earthquake hazard in the region. GSC scientists are continuing and extending such research in the region, thus contributing to a much more fundamental understanding of the hazard and how it may affect the region.

- Training the next generation of earth scientists. LITHOPROBE has actively involved more than 400 graduate and undergraduate students, postdoctoral fellows, and research associates who have learned their specific skills in an environment of multidisciplinary collaboration. Many of these scientists have gone on to employment in academia, government, and industry worldwide.

- Education and public awareness of science and technology. LITHOPROBE has provided educational material that has been used from high schools to university graduate courses. It has enhanced the visibility and relevance of the earth sciences as a discipline through a coordinated effort of public education and media communication. Industry representatives and politicians have been informed about the project.

- A new approach to collaborative science in Canada. The LITHOPROBE research network has redefined the nature of much earth science research in Canada. It has successfully fostered an unprecedented degree of cooperation among earth scientists in universities, federal and provincial/territorial geological surveys, and the mining and petroleum industries. It has spawned a new and healthy atmosphere of scientific 
cooperation among geologists, geophysicists, and geochemists who are working and learning together, thereby enhancing results beyond those that could be achieved through any one subdiscipline.

- Enhancing the international renown of Canadian earth science. Quality scientific results from LITHOPROBE's unique combination of collaborative research and multidisciplinary studies have been foremost in establishing the high international regard in which the project is held. LITHOPROBE is a model for similar projects in Canada and around the world. Indeed, EUROPROBE, a multidisciplinary, collaborative Earth science program in Europe, selected both its name and procedures based on the LITHOPROBE example (Gee and Zeyen, 1996). LITHOPROBE has been identified as the best model for a proposed new international consortium, sponsored by the International Lithosphere Programme, that will target fundamental geoscience problems of relevance to the global community.

\section{Acknowledgments}

LITHOPROBE is funded by the Natural Sciences and Engineering Research Council of Canada through the Research Networks Element of the Research Partnerships Program and by the Geological Survey of Canada (GSC). Glen Caldwell (University of Western Ontario) provided astute comments of a preliminary draft to improve readability for an international audience. LITHOPROBE publication no. 1023; GSC contribution no. 1998258.

\section{References}

Baird, D.J., Nelson, K.D., Knapp, J.H., Walters, J.J., and Brown, L.D., 1996, Crustal structure and evolution of the Trans-Hudson orogen: Results from seismic reflection profiling: Tectonics, v. 15, pp. 416-426.

Bank, C-G, Bostock, M.G., Ellis, R.M., Hajnal, Z., and VanDecar, J.C., 1998, Lithospheric mantle structure beneath the Trans-Hudson Orogen and the origin of diamondiferous kimberlites: Journal of Geophysical Research, v. 103, pp. 10,103-10,114.

Baragar, W.R.A., and R.F.J. Scoates, 1981, The Circum-Superior belt: a Proterozoic plate margin?, in A. Kroner, ed., Precambrian Plate Tectonics: Elsevier, Amsterdam, pp. 297-330.

Bardoux, M., David, J., Gariepy, C., and Robillard, M., 1996, A progress report on the geology and geochronology of the northeastern Rae Province in southeastern Ungava Bay, in R.J. Wardle and J. Hall, eds., Eastern Canadian Shield Onshore-Offshore Transect (ECSOOT) Meeting (March 14-15, 1996), The University of British Columbia, LITHOPROBE Report 57, pp. 44-58.

Bertrand, J-M., Roddick, J.C., Van Kranendonk, J.M., and Ermanovics, I., 1993, U-Pb Geochronology of deformation and metamorphism across a central transect of the Paleoproterozoic Torngat Orogen, North River map area, Labrador: Canadian Journal of Earth Sciences, v. 30, pp. 14701489.

Bickford, M.E., Collerson, K.D., Lewry, J.F., Van Schmus, W.R., and Chiarenzelli, J.R., 1990, Proterozoic collisional tectonism in the TransHudson orogen, Saskatchewan: Geology, v. 18, pp. 14-18.

Bickford, M.E., Collerson, K., Lewry, J., and Orrell, S., 1992, Pegmatites and leucogranites as probes of crust beneath allochthonous orogenic rocks in the Glennie and La Ronge domains: Saskatchewan Geological Survey, Saskatchewan Energy and Mines, Miscellaneous Report, 92-4, pp. 124129.

Blundell, D., Freeman, R., and Mueller, S., eds, 1992, A continent revealed: The European geotraverse: Cambridge University Press, Cambridge, UK, pp. 275.

Boerner, D., Milkereit, B., and Naldrett, A., eds, 1994, Special section on the LITHOPROBE Sudbury project: Geophysical Research Letters, v. 21, pp. 919-966.

Bostock, M.G., and VanDecar, J.C., 1995, Upper mantle structure of the northern Cascadia subduction zone: Canadian Journal of Earth Sciences, v. 32 , pp. $1-12$.

CANDEL, 1981, LITHOPROBE: Geoscience studies of the third dimensiona coordinated national geoscience project for the 1980s: Geoscience Canada, v. 8, pp. 117-125.
Carr, S.D., 1995, The southern Omineca Belt, British Columbia: new perspectives from Lithoprobe geoscience program: Canadian Journal of Earth Sciences, v. 32, pp. 1720-1739.

Clowes, R.M., 1984, Phase 1 LITHOPROBE: A coordinated national geoscience project: Geoscience Canada, v. 11, pp. 122-126.

Clowes, R.M., 1994, LITHOPROBE - Geoscience probing of inner space leads to new developments for mining exploration: CIM Bulletin, v. 87, pp. 36-48.

Clowes, R.M., Green, A.G., Yorath, C.J., Kanasewich, E.R., West, G.F., and Garland, G.D., 1984, LITHOPROBE - a national program for studying the third dimension of geology: Journal of the Canadian Society of Exploration Geophysicists, v. 20, pp. 23-39.

Clowes, R. M., Brandon, M., Green, A. G., Yorath, C. J., and SutherlandBrown, A., 1987, LITHOPROBE southern Vancouver Island: Cenozoic subduction complex imaged by deep seismic reflections: Canadian Journal of Earth Sciences, v. 24, pp. 31-51.

Clowes, R.M., Cook, F.A., Green, A.G., Keen, C.E., Ludden, J.N., Percival, J.A., Quinlan, G.M., and West, G.F., 1992, LITHOPROBE-New Perspectives on Crustal Evolution: Canadian Journal of Earth Sciences, v. 29, pp. 1813-1864.

Clowes, R. M., Zelt, C. A., Amor, J. R., and Ellis, R. M., 1995, Lithospheric structure of the southern Canadian Cordillera from a network of seismic refraction lines: Canadian Journal of Earth Sciences, v. 32, pp. 14851513.

Clowes, R.M., Baird, D.J, and Dehler, S.A., 1997, Crustal structure of the Cascadia subduction zone, southwestern British Columbia, from potential field and seismic studies: Canadian Journal of Earth Sciences, v. 34, pp. 317-335.

Collerson, K.D., Lewry, J.F., Van Schmus, R.W., and Bickford, M.E., 1989, Sm-Nd isotopic constraints on the age of the buried basement in central and southern Saskatchewan: Implications for diamond exploration: Summary of Investigations, Saskatchewan Geological Survey, Miscellaneous Report, 89-4, pp. 168-171.

Coney, P.J., Jones, D.L., and Monger, J.W.H., 1980. Cordilleran suspect terranes: Nature, v. 288, pp. 329-333.

Connelly, J.N., and Ryan, B., 1996, Late Archean evolution of the Nain Province, Nain, Labrador, Canada: Imprint of a collision: Canadian Journal of Earth Sciences, v. 33, pp. 1325-1342.

Cook, F. A., ed., 1995, The Southern Canadian Cordillera Transect of LITHOPROBE: Canadian Journal of Earth Sciences, v. 32, pp. 14831824.

Cook, F.A., Varsek, J.L., Clowes, R.M., Kanasewich, E.R., Spencer, C.S., Parrish, R.R., Brown, R.L., Carr, S.D., Johnson, B.J., and Price, R.A., 1992, LITHOPROBE crustal reflection cross section of the Southern Canadian Cordillera, 1, foreland thrust and fold belt to Fraser River fault: Tectonics, v. 11, no. 1, pp. 12-35.

Davis, E.E., and Lewis, T.J., 1984, Heatflow in a back-arc environment: Intermontane and Omineca Crystalline belts, southern Canadian Cordillera: Canadian Journal of Earth Sciences, v. 21, pp. 715-726.

Drew, J.J., and Clowes, R.M., 1990, A re-interpretation of the seismic structure across the active subduction zone of western Canada-CCSS Workshop Topic I, onshore-offshore data set, in Green, A.G., ed., Studies of Laterally Heterogeneous Structures Using Seismic Refraction and Reflection Data (Proceedings of the 1987 Commission on Controlled Source Seismology Workshop), Geological Survey of Canada, Paper 8913 , pp. $115-132$.

Dunphy, J.M., and Skulski, T., 1995, Early Proterozoic Granitic Magmatism in the Ungava and New Quebec Orogens: The Narsajuaq Terrane and the De Pas Batholith?, in R.J. Wardle and J. Hall, eds., Eastern Canadian Shield Onshore - Offshore Transect (ECSOOT) Meeting (November 2829, 1994), The University of British Columbia, LITHOPROBE Report 45, pp. 37-50.

Eaton, D.W., Milkereit, B., and Adam, E., 1997, 3-D seismic exploration, in "Proceedings of Exploration 97: Fourth Decennial International Conference on Mineral Exploration”, A.G. Gubins, ed., pp. 56-78.

Engebretson, D.C., Kelley, K.P., Cashman, H.J., and Richards, M.A., 1992, 180 million years of subduction: GSA Today, v. 2, pp. 94-95, 100.

Friedman, R.M., Mahoney, J.B., and Cui, Y., 1995, Magmatic evolution of the southern Coast Belt: Constraints from Nd-Sr isotopic systematics and geochronology of the southern Coast Plutonic Complex: Canadian Journal of Earth Sciences, v. 32, pp. 1681-1698.

Gabrielse, H., and Yorath, C.J., eds, 1991, Geology of the Cordilleran Orogen in Canada: Geological Survey of Canada, Geology of Canada, no. 4 (also Geological Society of America, The Geology of North America, v. G-2). 
Gee, D.G., and Zeyen, H.J., 1996, EUROPROBE 1996 - Lithosphere dynamics: Origin and evolution of continents: EUROPROBE Secretariat, Uppsala University, pp. 138.

Ghosh, D.K., 1995, Nd-Sr isotopic constraints on the interactions of the Intermontane Superterrane with the western edge of North America in southern Canadian Cordillera: Canadian Journal of Earth Sciences, v. 32, pp. 1740-1758.

Gibb, R.A., Hinze, W.J., and Thomas, M.D., eds, 1994, Potential field studies of continental rifts: The Great Lakes region: Canadian Journal of Earth Sciences, v. 31, pp. 617-720.

Gough, D.I., 1986, Mantle upflow tectonics in the Canadian Cordillera: Journal of Geophysical Research, v. 91, pp. 1909-1919.

Green, A.G., Clowes, R.M., Yorath, C.J., Spence, C.P., Kanasewich, E.R., Brandon, M.T., and Sutherland-Brown, A., 1986, Seismic reflection imaging of the subducting Juan de Fuca plate: Nature, v. 319, pp. 210213.

Hajnal, Z., Stauffer, M.R., White, D.J., Lucas, S.B., Lewry, J., Clowes, R.M., and Ashton, K.E., 1996, Three-dimensional seismic crustal signature of the western Trans-Hudson Orogen, Saskatchewan, in Hajnal, Z. and Lewry, J. (compilers), Trans-Hudson Orogen Transect, Report of 1996 Annual Workshop, The University of British Columbia, LITHOPROBE Report 55, pp. 113-124.

Hoffman, P.F., 1988, United plates of America, the birth of a craton: early Proterozoic assembly and growth of Laurentia: Annual Review of Earth and Planetary Sciences, v. 16, pp. 543-603.

Hoffman, P.F., 1989, Precambrian geology and tectonic history of North America, in The geology of North America - An overview: Geological Society of America, The Geology of North America, v. A, pp. 447-511

Hoffman, P.F., 1990, Dynamics of the assembly of northeast Laurentia in geon 18 (1.9 - 1.8 Ga): Geoscience Canada, v. 17, pp. 222-226.

Hyndman, R.D., and Wang, K., 1996, The rupture zone of Cascadia great earthquakes from current deformation and the thermal regime: Journal of Geophysical Research, v. 100, pp. 22,133-22,154.

Hyndman, R.D., Yorath, C.J., Clowes, R.M., and Davis, E.E., 1990, The northern Cascadia subduction zone at Vancouver Island: seismic structure and tectonic history: Canadian Journal of Earth Sciences, v. 27, pp. 313-329.

James, D.T., Connelly, J.N., Wasteneys, H.A., and Kilfoil, G.J., 1996, Paleoproterozoic lithotectonic subdivisions of the southeastern Churchill Province, western Labrador: Canadian Journal of Earth Sciences, v. 33, pp. 216-230.

Jones, A.G., and Gough, D.I., 1995, Electromagnetic images of crustal structures in southern and central Canadian Cordillera: Canadian Journal of Earth Sciences, v. 32, pp. 1541-1563.

Journeay, J.M., and Friedman, R.M., 1993, The Coast Belt thrust system: evidence of Late Cretaceous shortening in southwest British Columbia: Tectonics, v. 12, pp. 756-775.

Kurtz, R.D., DeLaurier, J.M., and Gupta, J.C., 1990, The electrical conductivity distribution beneath Vancouver Island: a region of active plate subduction: Journal of Geophysical Research, v. 95, pp. 10,929-10,946.

Leclair, A.D., Lucas, S.B., Broome, H.J., Viljoen, D.W., and Weber, W., 1997, Regional mapping of Precambrian basement beneath Phanerozoic cover in southeastern Trans-Hudson Orogen, Manitoba and Saskatchewan: Canadian Journal of Earth Sciences, v. 34, pp. 618-634.

Lewry, J.F., 1981, Lower Proterozoic arc-microcontinent collisional tectonics in the western Churchill Province: Nature, v. 294, pp. 69-72.

Lewry, J. F., and Stauffer, M. R., 1990, The Early Proterozoic Trans-Hudson Orogen of North America: Geological Association of Canada, Special Paper 37.

Lewry, J. F., Thomas, D.J., Macdonald, R., and Chiarenzelli, J., 1990, Structural relations in accreted terranes of the Trans-Hudson Orogen, Saskatchewan: Telescoping in a collisional regime?, in J.F. Lewry and M.R. Stauffer, eds, The Early Proterozoic Trans-Hudson Orogen of North America, Geological Association of Canada, Special Paper, 37, pp. 7594.

Lewry, J.F., Hajnal, Z., Green, A.G., Lucas, S.B., White, D.J., Stauffer, M.R., Ashton, K.E., Weber, W., and Clowes, R.M., 1994, Structure of a Paleoproterozoic continent-continent collision zone: A LITHOPROBE seismic reflection profile across the Trans-Hudson Orogen, Canada: Tectonophysics, v. 232, pp. 143-160.

Lucas, S.B., Green, A.G., Hajnal, Z., White, D.J., Lewry, J.F., Ashton, K.E., Weber, W., and Clowes, R.M., 1993, Deep seismic profile of a Proterozoic collision zone: Surprises at depth: Nature, v. 363, pp. 339-342.

Lucas, S.B., White, D., Hajnal, Z., Lewry, J., Green, A., Clowes, R., Zwanzig, H., Ashton, K., Schledewitz, D, Stauffer, M., Norman, A., Williams, P., and Spence, G., 1994, Three-dimensional collisional struc- ture of the Trans-Hudson Orogen, Canada: Tectonophysics, v. 232, pp. 161-178.

Lucas, S.B., Stern, R.A., Syme, E.C., Reilly, B.A. and Thomas, D.J., 1996, Intraoceanic tectonics and the development of continental crust: 1.92$1.84 \mathrm{Ga}$ evolution of the Flin Flon Belt (Canada): Geological Society of America Bulletin, v. 108, pp. 602-629.

Ludden, J.N., ed., 1994, The Abitibi-Grenville LITHOPROBE transect seismic reflection results. Part I: the western Grenville Province and Pontiac subprovince: Canadian Journal of Earth Sciences, v. 31, pp. 227-307.

Ludden, J.N., ed., 1995, Results from the Abitibi-Grenville LITHOPROBE transect. Part II: the Abitibi greenstone belt: Canadian Journal of Earth Sciences, v. 32, pp. 97-176.

Meyer, M.T., Bickford, M.E., and Lewry, J.F., 1992, The Wathaman batholith: a short-lived Early Proterozoic continental arc in the TransHudson Orogen, Canada: Geological Society of America Bulletin, v. 104, pp. 1073-1085.

Monger, J., Price, R., and Tempelman-Kluit, D., 1982, Tectonic accretion of two major metamorphic and plutonic welts in the Canadian Cordillera: Geology, v. 10, pp. 70-75.

Monger, J.W.H., Clowes, R.M., Cowan, D.S., Potter, C.J., Price, R.A., and Yorath, C.J., 1994, Continent-ocean transitions in western North America between latitudes 46 and 56 degrees: Transects B1, B2, B3, in Speed, R.C., ed., Phanerozoic Evolution of North American Continent-Ocean Transitions: Boulder, Colorado: Geological Society of America, DNAG Continent-Ocean Transect Volume, pp. 357-397.

Nelson, K.D., Baird, D.J., Walters, J.J., Hauck, M., Brown, L.D., Oliver, J.E., Ahern, J.L., Hajnal, Z., Jones, A.G., and Sloss, L.L., 1993, Trans-Hudson orogen and Williston basin in Montana and North Dakota: new COCORP deep-profiling results: Geology, v. 21, pp. 447-450.

Patchett, P.J., and Arndt, N.T., 1986, Nd isotopes and tectonics of 1.9-1.7 Ga crustal genesis: Earth and Planetary Science Letters, v. 78, pp. 329-338.

Percival, J., ed., 1994, The Kapuskasing Transect of LITHOPROBE: Canadian Journal of Earth Sciences, v. 31, pp. 1013-1286.

Scott, D., 1995, U-Pb geochronology of a Paleoproterozoic continental magmatic arc on the western margin of the Archean Nain craton, northern Labrador, Canada: Canadian Journal of Earth Sciences, v. 32, pp. 18701882.

Scott, D., 1996, Geology of the Hall Peninsula east of Iqaluit, southern Baffin Island, Northwest Territories, in Current Research, Geological Survey of Canada, Paper 96-1C, pp. 83-91.

Scott, D., 1997, Geology, U-Pb \& Pb-Pb geochronology of the Lake Harbour area, southern Baffin Island: Implications for the Paleoproterozoic tectonic evolution of NE Laurentia: Canadian Journal of Earth Sciences, v. 34 , pp. $140-155$

Scott, D., and Machado, N., 1995, U-Pb geochronology of the northern Torngat Orogen, Labrador, Canada: A record of Paleoproterozoic magmatism and deformation: Precambrian Research, v. 70, pp. 169-190.

Scott, D., and Gauthier, G., 1996, Ages of detrital zircons in Paleoproterozoic metasediments from northeastern Laurentia using TIMS (U-Pb) and laser ablation microprobe ICP-MS (Pb): Comparison of techniques and implications for the tectonic evolution of the region: Chemical Geology, v. 131 , pp. 127-142.

Scott, D. and St-Onge, M.R., 1998. Paleoproterozoic assembly of northeast Laurentia revisited: A model based on southward extrapolation of Ungava - Baffin crustal architecture, in Wardle, R.J. and Hall, J. (compilers), Eastern Canadian Shield Onshore-Offshore Transect (ECSOOT), Report of 1998 Annual Workshop, The University of British Columbia, LITHOPROBE Report 68, pp.134-147.

Stauffer, M.R., 1984, Manikewan: an Early Proterozoic ocean in central Canada, its igneous history and orogenic closure: Precambrian Research, v. 25 , pp. $257-281$.

Stern, R.A., Syme, E.C., Bailes, A.H., and Lucas, S.B.,1995a, Paleoproterozoic (1.90-1.86 Ga) arc volcanism in the Flin Flon Belt, Trans-Hudson Orogen, Canada: Contributions to Mineralogy and Petrology, v. 119, pp. 117-141.

Stern, R.A., Syme, E.C., and Lucas, S.B., 1995b, Geochemistry of $1.9 \mathrm{Ga}$ MORB- and OIB-like basalts from the Amisk collage, Flin Flon Belt, Canada: Evidence for an intra-oceanic origin: Geochimica et Cosmochimica Acta, v. 59, pp. 3131-3154.

St-Onge, M.R., Scott, D.J., Wodicka, N., and Lucas, S.B., 1998. Geology of the McKeller Bay - Wight Inlet - Frobisher Bay area, southern Baffin Island, Northwest Territories. Geological Survey of Canada, Paper 1998C: $43-53$.

Symons, D.T.A., 1998, Precambrian plate tectonic models: Shifting the paleomagnetic paradigm for orogens such as the Trans-Hudson in Canada: Physics and Chemistry of the Earth, v.23, pp.753-759. 
Theriault, R.J., 1998. Nd and $\mathrm{Pb}$ isotopic and geochemical framework of Paleoproterozoic southern Baffin Island, and comparisons with other segments of the eastern Trans-Hudson Orogen, in Wardle, R.J. and Hall, J. (Compilers), Eastern Canadian Shield Onshore-Offshore Transect (ECSOOT), Report of 1998 Annual Workshop, The University of British Columbia, LITHOPROBE Report 68, pp.170-187.

Theriault, R.J., and Ermanovics, I., 1997, Sm-Nd isotopic and geochemical characterization of the Paleoproterozoic Torngat orogen, Labrador, Canada: Precambrian Research, v. 81, pp. 15-35

Thom, A., Arndt, N.T., Chauvel, C., and Stauffer, M.R., 1990, Flin Flon and western La Ronge belts, Saskatchewan: Products of Proterozoic subduction-related volcanism, in J.F. Lewry and M.R. Stauffer, eds., The Early Proterozoic Trans-Hudson Orogen of North America, Geological Association of Canada, Special Paper, v. 37, pp. 163-176.

Van Kranendonk, M.J., 1996, Tectonic evolution of the Paleoproterozoic Torngat Orogen: Evidence from pressure-temperature-time deformation paths in the North River map area, Labrador: Tectonics, v. 15, pp. 843869.

Van Kranendonk, M.J., and Wardle, R.J., 1996, Burwell domain of the Palaeoproterozoic Torngat Orogen, northeastern Canada: Tilted crosssection of a magmatic arc caught between a rock and a hard place, in T.S. Brewer, ed., Precambrian Evolution in the North Atlantic Region, Geological Society Special Publication, v. 112, pp. 91-115.

Van Kranendonk, M.J., St-Onge, M.R., and Henderson, J.R., 1993, Paleoproterozoic tectonic assembly of Northeast Laurentia through multiple indentations: Precambrian Research, v. 63, pp. 325-347.

Van Schmus, W.R., Bickford, M.E., Lewry, J.F., and Macdonald R., 1987, $\mathrm{U}-\mathrm{Pb}$ geochronology in the Trans-Hudson, northern Saskatchewan, Canada: Canadian Journal of Earth Sciences, v. 24, pp. 407-424.

Wardle, R.J., and Van Kranendonk, M.J., 1996, The Palaeoproterozoic Southeastern Churchill Province of Labrador-Quebec, Canada: Orogenic development as a consequence of oblique convergence and indentation, in T.S. Brewer, ed., Precambrian Evolution in the North Atlantic Region, Geological Society Special Publication, v. 112, pp. 137-153.

Wares, R.P., and Goutier, J., 1990, Deformational style in the foreland of the New Quebec Orogen: Geoscience Canada, v. 17: pp. 244-249.

Wheeler, J.O., and McFeely, P., 1991, Tectonic assemblage map of the Canadian Cordillera and adjacent parts of the United States of America: Geological Survey of Canada, Map 1712A, scale 1:2 000000.

Wood, D.A., 1980, The application of a Th-Hf-Ta diagram to problems of tectonomagmatic classification and to establishing the nature of crustal contamination of basaltic lavas of the British Tertiary volcanic province: Earth and Planetary Science Letters, v. 50, pp. 11-30.
Frederick A. Cook is a professor in the Department of Geology and Geophysics at the University of Calgary, Canada. He received his B. Sc. in geology in 1973 and his Ph.D. in geophysics from Cornell University in 1981. He has been Director of the LITHOPROBE Seismic Processing Facility at the University of Calgary since 1987, and is transect leader of the LITHOPROBE Southern Canadian Cordillera transect and transect co-leader for the LITHOPROBE Slave-Northern Cordillera Lithospheric Evolution (SNORCLE) transect.

Zoltan Hajnal received a Ph.D. (1970) in geophysics from the University of Manitoba, after which he moved to the University of Saskatchwan where he is currently a Full Professor. In 1989, he became transect co-leader of LITHOPROBE's Trans-Hudson Orogen Transect. His personal research involves analysis and synthesis of refraction and reflection from shallow crustal to deep lithospheric depths. He served as president of Canadian Geophysical Union and councilor of Geological Association of Canada from 1982 to 1984. He is a member of SEG, CSEG, AGU, CGU and EAGE.

Jeremy Hall is a seismologist with research interests in the continental crust and the processes that form and reform it. He has studied the Appalachian/Caledonide system in Britain and Canada, the Archean and Proterozoic foundations that lie within and around $i$, and the sedimentary basins that succeed it. He is also working on modern analogs among the young convergent plate margins of eastern Europe and the Mediterranean. He has been transect coleader of the LITHOPROBE ECSOOT project since 1990.

John Lewry is a field-oriented, structural/metamorphic and Precambrian geologist who received his B.Sc. (1960) and Ph.D. (1964) from University College of Wales, Aberystwyth. He has been a faculty member in the Geology Department, University of Regina since 1968, where he is now professor emeritus. In recent years, he has been transect co-leader of the LITHOPROBE Trans-Hudson Orogen Transect.

Stephen Lucas received his B.Sc. in geological engineering from Queen's University in 1984 and his Ph.D. from Brown University in 1989, joining the Geological Survey of Canada in 1989. He co-led the NATMAP Shield Margin Project in the Flin Flon Belt, and has been actively involved in LITHOPROBE's Trans-Hudson Orogen Transect. He is a member of the Pan-LITHOPROBE Subcommittee and LITHOPROBE Seismic Reprocessing Grant Review Panel.

Richard Wardle graduated from Liverpool University in 1971 and obtained a Ph.D. in geology from the University of New Brunswick, Canada, in 1978. He joined the Newfoundland Geological Survey in 1976 to commence a mapping career in Labrador that took him into various parts of the Churchill, Grenville and Nain provinces. The more recent focus of his work has been on the geology of the northern Torngat Orogen. He served as head of Labrador mapping until 1998 and is currently head of the Mineral Deposits section. He has been transect coleader of the LITHOPROBE ECSOOT project since its inception in 1990. 